\title{
A DECISION SUPPORT SYSTEM (DSS) FOR CRITICAL LANDSLIDES AND ROCKFALLS AND ITS APPLICATION TO SOME CASES IN THE WESTERN ITALIAN ALPS
}

5 Davide Bertolo ${ }^{1}$

${ }^{1}$ Struttura organizzativa attività geologiche, Regione Autonoma Valle d'Aosta, Quart (AO), 11020, Italy.

Correspondence to: Davide Bertolo (d.bertolo@regione.vda.it)

\section{Abstract}

Operative geologists who are involved in emergency management have often to deal with the consequences of assuming critical and strongly impacting decisions in uncertain conditions.

Geohazards induced by active landslides are one of the civil protection situations requiring such decisions.

Nowadays, the monitoring of active landslides is almost always supported by numerical early warning systems, based on instrumental geotechnical and topographic networks. These networks provide numerical early warning thresholds, which are set up in order to activate alert conditions at various levels of criticality in an objective way.

Despite these progresses the issue related to the possibility to dispatch false alerts has not yet effectively solved and that's the reason why the critical stages of the decisional processes are frequently relying not only on quantitative thresholds but also on the subjective experience of the emergency managers.

Therefore it is not so uncommon to read landslide-monitoring procedures that combine the quantitative information provided by the monitoring systems with the qualitative decisional elements coming from their professional experience in order to assume the most correct decision.

It's therefore evident that such an approach weakens the objectiveness provided by instrumental monitoring systems but, at the same time, collecting geological empirical and qualitative data can strengthen an hypothesis like the one that an active landslide could finally collapse.

Bayesian methods are frequently used in clinical decision making, another field of the human activity where critical decisions have to be made in a short time, combining objective values such as those provided by medical tests with diagnostic qualitative markers.

Based on the methods of clinical diagnosis, the has author has elaborated a reliable and objective Bayesian Decision Support System (or DSS), developed to support the decision makers in assuming the most correct decisions based on all the elements, both quantitative and qualitative, that are available at a certain step of the decision process.

Thanks to the Bayesian approach, the DSS allows also to assess the predictivity of any single decisional step, which is the probability that a monitored landslide actually collapses when particular diagnostic evidences are detected, either instrumental or observational.

Hence the decision makers who are able to issue a civil protection alert when a given degree of confidence about the chance that a monitored landslide will collapse is reached. The degree of 
Nat. Hazards Earth Syst. Sci. Discuss., https://doi.org/10.5194/nhess-2017-396

Manuscript under review for journal Nat. Hazards Earth Syst. Sci.

Discussion started: 30 November 2017

(c) Author(s) 2017. CC BY 4.0 License.

confidence associated to the civil protection alert can be declared in the alert bulletin (e.g.: $80 \%$ or 93\%). The decisional process can be tracked and replied by everyone in complete transparency.

It's therefore evident that such a DSS allows the civil protection authorities to increase the reliability of the alerts, reducing at the same time the so-called "cry wolf" effect and the discomfort related to evacuations and to other civil protection measures. As a matter of fact, the decisional process becomes clearer and the people's trust in the civil protection systems is being strengthened by a more transparent emergency communication.

The DSS here described is an evolution and a statistical improvement of the method adopted in 2013 and 2014 during the emergency of the Mont the la Saxe landslide, and is now being successfully applied

10 to two other hazardous situations in the Aosta Valley Alps: the Brenva Site (Mont Blanc Massif) and the Berlachu site in the municipality of Lillianes (Lower Lys Valley).

\section{The DSS fundamentals}

The rationales at the basis of the numerical methods for landslide monitoring are well known and are adopted by nearly every operator in the field of the natural hazard managing.

15 During the last years the numerical monitoring has gained an unquestionable supremacy on all the other "qualitative" monitoring and surveying methods and enhanced by the developments in the accuracy of the remote and contact monitoring instrumentations (Terzaghi, 1950; Dunnicliff, 1994).

Furthermore, during the last decades the increasing availability of numerical data has supported the development of empirical and statistical methods, in the effort to implement reliable landslide early warning systems based on objective thresholds (Voight, 1988; Voight, 1989).

Today, these statistical methods, widely adopted for landslide monitoring, can't be successfully used without being placed within a larger and harmonic logical framework, which should be aimed to correctly manage hazardous and emergency situations.

In this light, it has become necessary to have a global framework including allowing a comprehensive approach to these kind of phenomena (Crosta et al., 2012), including also an analysis of the targets at stake, the civil protection measures adopted to protect human lives and the economic assets, the impacts coming from the enforcement of the civil protection measures and an effective risk communication system.

The assumptions at the basis of the method proposed in this paper rely on some famous studies about

30 human behavior in decisional processes and the cognitive biases which influence these activities (Kahneman and Tvertsky, 1979).

The two authors demonstrated that human behavior, facing decisions implying potential losses, is usually biased by the so-called "risk aversion" mechanism: the human brain, facing risky choices, tends to emphasize losses and to choose conservative solutions.

35 On the other hand, when the so-called "overconfidence" prevails in judgments, often sustained by a consistent professional experience, this is the kind of behavior that can easily lead to catastrophic effects (Pulford and Colman, 1996; Kahneman D., 2011). Other biases, like the "confirmation bias" will be also examined as factors potentially influencing a decisional process.

As previously said, when monitoring active landslides, one way to overcome these biases has been, so

40 far, the adoption of numerical models based on instruments able to detect even the smaller 
Nat. Hazards Earth Syst. Sci. Discuss., https://doi.org/10.5194/nhess-2017-396

Manuscript under review for journal Nat. Hazards Earth Syst. Sci.

Discussion started: 30 November 2017

(c) Author(s) 2017. CC BY 4.0 License.

displacements and to implement early warning DSS exclusively based on these instruments and warning thresholds.

Nevertheless, the overconfidence about the capacity of a completely automatized system to be absolutely reliable without any human intervention could lead to a substantial underestimation of 5 qualitative evidences.

Such evidences, which are the so-called "expert judgments", are usually based on the observation of terrain evidences, which are equally worth to be weighted in the decision process. Regarding large landslides, among these evidences are well known qualitative signs such as the appearance of fractures, smaller rockfall frequency increase, and so on.

10 When applied to a real civil protection emergency situation, the mixing of the two kind of data often produce quite aleatory results, because in several EW procedures the early warning decisional stages based on automatic monitoring networks are followed by further and not well defined "advices from experts" or "geological field investigations", to be acquired once the EWS quantitative values have been exceeded in order to support the issuing of the alerts.

15 It is therefore obvious that, when expert judgments are required to support decisions in the advanced stages of the EW procedures, the opposite biases of risk aversion or overconfidence will probably shift the expert judgments, made by humans, either to confirm the numerical values (risk aversion) or, even worse, to refute or underestimate the numerical results coming from the EWS networks under the overconfidence bias.

20 To further complicate that framework, here comes today the increasing availability of a great amount of data provided by the monitoring networks, particularly when an instability is continuously monitored by different redundant networks at an high-frequency sampling rate.

As it will be shown later, the implementation of a Bayesian DSS of the type here described, contributes to establish a "network hierarchy" will make also easy to assess which are the best monitoring systems

25 in order to provide the decision-makers the best monitoring technologies to support their evaluations.

The DSS has been implemented by the geological survey (Struttura attività geologiche) of the Valle d'Aosta Autonomous Region and is being successfully tested at three test sites on the regional territory, with different kinds of slope instability.

\subsection{The Mont de La Saxe landslide experience 2012-2014}

30 In order to correctly explain the bases of the proposed method, the experience made by the regional geological survey in monitoring the evolution of the Mont de La Saxe landslide since 2012 will be described.

The Mont de La Saxe Landslide is one of the most active and dangerous large slope instabilities in the Alps. According to current estimates, it involves an area of about $150.000 \mathrm{~m}^{2}$, with a maximum width

35 of $350 \mathrm{~m}$ and a maximum length of $500 \mathrm{~m}$. The total mass potentially involved in a collapse is about 8,0 $\div 8,5 * 10^{6} \mathrm{~m}^{3}$. The potential collapse threatens an important touristic resort in the western Italian Alps and important infrastructures such as the Mont Blanc Tunnel and the E25 Motorway which are among the most important road links between the industrial areas of northwestern Italy, France and Switzerland. (Fig. 1) 
Nat. Hazards Earth Syst. Sci. Discuss., https://doi.org/10.5194/nhess-2017-396

Manuscript under review for journal Nat. Hazards Earth Syst. Sci.

Discussion started: 30 November 2017

(c) Author(s) 2017. CC BY 4.0 License.

The importance of the targets at stake led to the implementation of a very redundant and performing monitoring EW system, active since 2009.

The first EW procedure, elaborated in 2008, followed the classical and common approach to the alert dispatching system, based on the exceeding of two velocity thresholds, respectively of $V_{24}=1 \mathrm{~mm} / \mathrm{h}$

5 (pre-alarm condition) and $\mathrm{V}_{24}=2 \mathrm{~mm} / \mathrm{h}$ (alarm condition). The two thresholds are calculated measuring hourly the surface slope deformation by a robotized total station (RTS) on about 30 optical targets placed on the unstable slope. The $\mathrm{V}_{24}$ values come from the calculation of the mean of the hourly measurements on a 24-hour time interval.

The displacement thresholds are calculated applying the Voight model (Voight, 1989; Tamburini and

10 Martelli, 2006). The overcoming of the alert threshold of $\mathrm{V}_{24}=2 \mathrm{~mm} / \mathrm{h}$ required the dispatching of an alert message to the civil protection authorities and should be followed by a quite unclear "consulting phase" in which experts had to be consulted and further investigations should be undertaken.

On may 5", 2012, the EW network detected the first exceeding of a warning threshold since its activation in 2009. The following field investigations showed that a cinematic-structural domain of the

15 monitored landslide, involving a volume of about $650.000 \mathrm{~m}^{3}$ (C domain in Fig 2.) was becoming unstable. $\mathrm{V}_{24}$

After about 30 days, the displacement velocity of the $\mathrm{C}$ domain returned below the threshold of $\mathrm{V}_{24}=$ $2 \mathrm{~mm} / \mathrm{h}$ and the alarm condition was revoked. Terrain evidences like neo-formation scarps and fractures appeared during the summer 2012, as a sign of an in-progress evolutionary process.

20 In 2013, at the end of March, the combination of a thick snow cover (about 2000 mm cumulated snow cover), suddenly melted by a warm föhn wave, triggered a massive activation of the unstable domain. The destabilization of the $\mathrm{C}$ domain was followed by the activation on the entire unstable slope, due to the "recall" effect of the neighboring sectors. The risk of a multiple sequential failure potentially leading to the collapse of the whole landslide became real.

25 Consequently, from 19/04/2013 to 24/06/2013 the massive activation forced the geological survey to issue a new warning. An estimated $650.000 \mathrm{~m}^{3}$ volume could collapse, potentially followed by the collapse of the entire unstable slope. The municipality of Courmayeur evacuated about 100 people and the access to the Val Ferret was interrupted. The emergency condition lasted for about 40 days and the alert thresholds set at $2 \mathrm{~mm} / \mathrm{h}$ were uninterruptedly surpassed for nearly two months (maximum value

30 of $\mathrm{V}_{24}=7 \mathrm{~mm} / \mathrm{h}$ ). Nevertheless no collapse happened.

These experiences made it clear that the $\mathrm{V}_{24}=2 \mathrm{~mm} / \mathrm{h}$ threshold was not compliant to the real behavior of the landslide. Therefore, the decisional process in the EW procedure was integrated with a series of further decisional elements (Bertolo, 2013), which will be named later as decisional values.

A further and consistent proof of the inadequacy of the single-threshold approach finally came when the

35 landslide displacement rate newly increased at the end of March 2014, reaching in the C domain displacements up to $500 \mathrm{~mm} /$ hour. The emergency reached its top events with two main collapses from the $\mathrm{C}$ sector on April $17^{\text {th }}$ and April $21^{\text {th }}$, 2014, with two single collapses respectively of $5 \times 10^{3} \mathrm{~m}^{3}$ and 
Nat. Hazards Earth Syst. Sci. Discuss., https://doi.org/10.5194/nhess-2017-396

Manuscript under review for journal Nat. Hazards Earth Syst. Sci.

Discussion started: 30 November 2017

(c) Author(s) 2017. CC BY 4.0 License.

$3 \times 10^{4} \mathrm{~m}^{3}$ each one. The rest of the domain C slowly collapsed transforming with an earthflow rheology and not threatening the targets. At the end of June 2014, the whole C domain had collapsed. Thanks to a procedure involving multiple decisional elements, the E25 route was closed only 3 hours and people had been evacuated for about 40 days, even if the instability had become more critical than in 2013.

5 The emergency management during 2013 and 2014 landslide activation performed very well, providing a relevant outcome of best practices in many domains, such as risk communication (Giordan et al, 2014) and failure potential forecasting methods (Manconi and Giordan, 2015).

During these emergencies the EW procedure was amended adopting a flexible approach: the exceeding of the $\mathrm{V}_{24}$ threshold led to an intensified surveillance phase, in which other elements such as the $\mathrm{V}_{24}$

10 increasing in surrounding sectors and the in-depth acceleration detected by multiparametric probes, where adopted as decisional values to support the final decision to dispatch the civil protection alerts.

Thus, being able to adapt the alert dispatching with a "learn as you go" method (Peck, 1969) showed to be an efficient way, minimizing the impact on the population lifestyle and local economy by the civil protection plan enforcement, assuring at the same time an appropriate safety level.

15 Despite that satisfactory experience, the method applied in 2013 and 2014, that integrated multiple decisional values, remained substantially a qualitative/quantitative mixed one, with a basically empirical and heuristic approach.

To achieve a stronger and comprehensive method to integrate, manage and capitalize all the potentialities given by an integrated monitoring system it was therefore necessary to develop an

20 objective, mathematical method, being able to take profit from the successful decisional processes followed during the 2013 and 2014 emergencies. That need led to the development of a decision support system (DSS) suitable to dispatch alerts, with a clear probabilistic and replicable degree of confidence and that can be successfully used both on large landslides and on smaller medium-size slope instabilities.

25 To implement the DSS, the Author has looked to the domains of the human activity where, like in the applied geology, qualitative and quantitative data have to be integrated in order to make decisions about critical issues. The results of that research showed that the medical diagnosis is one of the most prominent human activities where advanced studies and decisional protocols showing such features have been elaborated.

30 Medical clinical diagnostic processes show a great similarity with EW operational geology: the need to integrate quantitative data produced by highly technological systems with qualitative data gathered with traditional methods, the difficulty in modeling the real situation due to the extremely complex setting of the subject under investigation, the lack of data coming for in-depth direct investigations due to their cost and terrain difficulties, and most of all, the need to assume decisions rapidly collecting all the available data to assume the correct decision.

The problem in assessing the probability of slope collapses is almost quite the same of the medical clinic, when the assigned task is to find a method to assess the probability of the collapse of an unstable slope, given the appearance of a diagnostic signal, such as the exceeding of a given threshold (quantitative) or the appearance of trenches (qualitative). 
Nat. Hazards Earth Syst. Sci. Discuss., https://doi.org/10.5194/nhess-2017-396

Manuscript under review for journal Nat. Hazards Earth Syst. Sci.

Discussion started: 30 November 2017

(c) Author(s) 2017. CC BY 4.0 License.

\subsection{Estimating the Predictive Positive Value of EW thresholds under an operative Bayesian approach}

In medicine DSS assuming both objective test data (pathological approach) and expert observations (clinical approach) are by now given as consolidated and widely applied in diagnosing diseases and in

5 performing wide scale screenings (Dixon-Woods et al, 2005; Voils et al., 2009.)

One of the most reliable mathematic-based approaches, providing the ability to integrate quantitative and qualitative data, is the Bayesian approach (Bayes, 1706). Under the Bayesian approach all the elements leading to a "highly confident" decision are ruled by the Bayes Theorem and by its applications to the evaluation and decision process.

10 It is well known that, since the mid '90s, Bayesian methods are being applied to geohazards and in EWS theoretical design too, emphasizing the opportunity to integrate in the decision processes different data coming from different sources, thus refining the models and the hazard forecasts (Medina-Cetina and Nadim, 2007; Michoud et al., 2013).

To implement a Bayesian DSS method suitable to landslides or landslides, it was assumed that each

15 qualitative or quantitative evaluation, worth to be inserted in the DSS process, could be assimilated to a diagnostic test providing what is called the "decisional value". A decisional value is any quantitative or qualitative evidence being able to support (or not) hypothesis of the final collapse of the whole unstable slope.

To show the usefulness of the Bayesian method, it may be used to assess the fallacy of a single-

20 threshold DSS in the case it is based only on the exceeding of the $V_{24}=2 \mathrm{~mm} / \mathrm{h}$ threshold measured by an instrument like a RTS (the use of other instruments like GPS or a GbSAR will yield the same results).

The real case is that of the Mont the la Saxe landslide EWS procedure before its first amendment in 2013.

25 The early warning $\mathrm{V}_{24}=2 \mathrm{~mm} / \mathrm{h}$ threshold based on the Voight model is assumed as a test, or marker, which, if positive (the case in which $\mathrm{V}_{24}=2 \mathrm{~mm} / \mathrm{h}$ is exceeded), provides a decisional value leading to the immediate dispatching of the alert condition to the civil protection authorities.

As said in the introduction, one of the main assumptions supporting the use of a Bayesian DSS is that it can provide the decision makers the degree of confidence associated to any single decisional value

30 during the decisional process, that is called the Positive Predictive Value, or PPV (Rothman K. J., 2012).

The PPV expresses as degree of confidence about the likelihood of the original hypothesis on the basis of the elements available at a certain moment. If the PPV of a single decisional value will be too low, then it will be necessary to look for other elements supporting or not the original hypothesis, the so-

35 called Null Hypothesis or $\mathrm{H}_{0}$ (Neyman and Pearson, 1933).

If the PPV of a single decisional value will be too low, then it will be necessary to look for other elements supporting or not the original hypothesis, the so-called Null Hypothesis or H0 (Neyman and Pearson, cit.). 
Nat. Hazards Earth Syst. Sci. Discuss., https://doi.org/10.5194/nhess-2017-396

Manuscript under review for journal Nat. Hazards Earth Syst. Sci.

Discussion started: 30 November 2017

(c) Author(s) 2017. CC BY 4.0 License.

Therefore, in the case of an EWS based on surface displacement, calculating the PPV of the " $\mathrm{V}_{24}$ test" means answering the following question: if the exceeding of $\mathrm{V}_{24}=2 \mathrm{~mm} / \mathrm{h}$ is being observed, what will be the probability to observe the whole collapse of the unstable slope?

Applying the Bayes theorem, the PPV of $\mathrm{V}_{24}=2 \mathrm{~mm} / \mathrm{h}$ threshold test will be:

$$
\text { [1] } \quad \mathrm{P}(A \mid B)=\frac{\mathrm{P}(\mathrm{B} \mid \mathrm{A}) \mathrm{P}(\mathrm{A})}{\mathrm{P}(\mathrm{B})}=H_{0}
$$

Where and A and B are, respectively, the occurrence of the whole collapse event and the exceeding of the threshold (the observed datum). $\mathrm{P}(B \mid A)$ is therefore the conditional probability that, given the exceeding of the $\mathrm{V}_{24}=2 \mathrm{~mm} / \mathrm{h}$ threshold the monitored landslide actually collapse, that is the "Predictive Positive Value" of the test or, vice-versa, the likelihood of $\mathrm{H}_{0}$ under a single test.

10 To do so, three fundamental parameters influencing the predictive value of the $\mathrm{V}_{24}>2 \mathrm{~mm} / \mathrm{h}$ test have to be assessed:

1. The Sensitivity (Se): the percentage of unstable slopes that, in a particular area (local, regional, or wider) at the time of their collapse, actually had exceeded $\mathrm{V}_{24}=2 \mathrm{~mm} / \mathrm{h}$;

2. The Specificity (Sp): the percentage of active instabilities that, once exceeded the $V_{24}=2 \mathrm{~mm} / \mathrm{h}$ threshold, actually collapsed that is, in medical language, the "true positives". The inverse of this parameter, that is 1-Sp is the percentage of "false positives" that is the percentage of instabilities that, despite exceeding the $\mathrm{V}_{24}=\mathrm{mm} / \mathrm{h}$ threshold didn't collapsed (Fig. 3);

3. The Prevalence (Pr): this the observed frequency of the active landslide phenomena at a certain time in a certain geographic domain. This parameter varies widely depending on the extension of the area examined (local, regional, continental, worldwide) thus it is very difficult to estimate. Therefore, the choice of the area on which the Pr is evaluated is critical because, since landslides occur in mountains or hill regions, a wide scale assessment of Pr, involving also plain regions, will probably lead to unlikely and low Pr ratios. Moreover, Pr may be also influenced by the environmental changes, like global warming or rainfall increase, hence the assesment of Pr should take into account not only the area in which it's calculated but even the time interval adopted for the calculation.

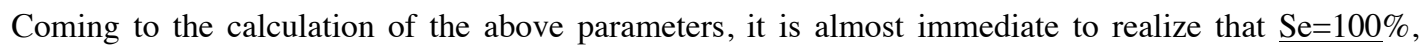
because every recorded catastrophic landslide at its collapse (terminal velocity) exceeds the $V_{24}=2 \mathrm{~mm} / \mathrm{h}$ threshold. By contrast, $\mathrm{Sp}$ is more difficult to assess, mainly due to the too short historical records of instrumental monitored landslides available for that kind of statistical analysis, (Crosta and Agliardi, 2003; Mazzanti et al., 2015).

Applying the corrections required by the estimation of $\operatorname{Pr}, \operatorname{Pr}, \mathrm{Se}$, the [1] becomes:

$$
\text { [2] } \quad P P V=\frac{\text { Sensitivity } * \text { Prevalence }}{\text { Sensitivity } * \text { Prevalence }+(1-\text { Specificity }) *(1-\text { Prevalence })}
$$


Nat. Hazards Earth Syst. Sci. Discuss., https://doi.org/10.5194/nhess-2017-396

Manuscript under review for journal Nat. Hazards Earth Syst. Sci.

Discussion started: 30 November 2017

(c) Author(s) 2017. CC BY 4.0 License.

$\mathrm{Sp}=0,80$ : that is in $80 \%$ of the cases the instabilities that exceeded $\mathrm{V}_{24}=2 \mathrm{~mm} / \mathrm{h}$ actually collapsed, while in the remaining $20 \%$ of the cases the instabilities, even if they exceeded the threshold, didn't collapse, thus $20 \%$ is the percentage of "false positives" detected by the test. The conservative nature of that choice is due to the small sample on which the $V_{24}$ threshold has been estimated.

$5 \mathrm{Pr}$, as said before, is perhaps one of the hardest parameters to calculate, due to the difficulty to gather accurate estimates about the statistical incidence of the different types of landsides.

On the other hand, estimating an high value of Pr will lead to an overestimation of the PPV of the test, which, all in all, is a conservative outcome, therefore functional to our demonstration and suitable to be included in a civil protection EW system without leading to risky decisions due to overconfidence.

10 In this case Pr has been calculated on the basis of the Aosta Valley Autonomous Region landslide susceptivity calculated in the IFFI landslide phenomena inventory (Giardino and Ratto, 2007). According to the IFFI inventory the Aosta Valley Autonomous Region, with a total surface of 3.262 $\mathrm{km}^{2}$, is one of the Italian territories most affected by landslides. Pr has therefore been estimated as the ratio between unstable surface and total regional area, which is very high, ranging around $15 \%$. This

15 value appears to be consistent with the values calculated by examining other landslide inventories (Malamud et al. 2004).

Applying the values in the [2], the PPV is:

$$
\text { [3] } P P V(V 24 m m)=\frac{1 * 0,15}{1 * 0,15+(1-0,80) *(1-0,15)}=46,88 \% \approx 47 \%
$$

20 This result clearly shows that an EWS based only on a single surface displacement velocity will reach at its best a PPV of $47 \%$ (which means a 53\% probability of dispatching a false alarm). And it's worth noting that this poor confidence value is reached with a conservative approach, assuming a high value of prevalence of the landslide type and assuming that $80 \%$ of the landslides that exceed the $\mathrm{V}_{24}$ threshold will actually collapse $(\operatorname{Pr}=80 \%)$.

25 Sp is greatly influenced by the amplitude of the sample and all the studies to calculate the displacement velocity parameter adopt the back analysis method, meaning that these studies rely on the very small sample made by historical landslides. This small representativeness of the sample is another limit of the velocity-based thresholds, which becomes evident if it is uncritically adopted as an exclusive basis of an EWS.

30 Another important factor influencing the PPV of the $\mathrm{V}_{24}$ threshold comes from the intrinsic nature of the sample used to evaluate the threshold itself. The sample is, indeed, almost always based on backanalyses performed on unstable slopes that in most cases actually collapsed (Crosta and Agliardi, cit.). This circumstance greatly affects the value of $\operatorname{Pr}$ and leads to overestimating the "false positives", thus leading to predict the collapses of slopes that actually will not collapse at all.

\subsubsection{Examining a DSS exclusively based on the inverse velocity method}

Another widely used approach to landslide monitoring is the inverse velocity method (Fukuzono, 1985). It has been recently re-elaborated and tested, in-parallel with the Voight method, during the Mont de La 
Nat. Hazards Earth Syst. Sci. Discuss., https://doi.org/10.5194/nhess-2017-396

Manuscript under review for journal Nat. Hazards Earth Syst. Sci.

Discussion started: 30 November 2017

(c) Author(s) 2017. CC BY 4.0 License.

Saxe emergency of 2014 (Manconi and Giordan 2015). In their work the two authors performed an estimation of the reliability (R) of this test, obviously assuming that the reliability of the forecast is poised to increase when approaching the Time of Failure or ToF.

If the inverse velocity method is embedded in a Bayesian DSS, assuming a conservative approach, even

5 for the inverse velocity method, the Se of the test can be fixed at a value of $\mathrm{Se}=75 \%$ that, according to the cited two authors, can be considered as an high reliable value. Since the inverse velocity method increases its reliability (the PPV) approaching to the ToF and since civil protection plans have to be activated with the due advance in order to ensure public safety, there is a consistent risk that decision makers approach too much to the $\mathrm{ToF}$ in order to dispatch a reliable alert.

10 Nevertheless, even if the decision-makers decide to take the above-mentioned risk, once the threshold is exceeded, the PPV of the test will only be $41.3 \%$, with a probability of false warnings of $58.7 \%$.

In fact, as suggested by Rose and Hungr (cit.), the method should not be used as stand-alone but should be sustained by further quantitative or qualitative observations.

The two examples clearly show that when it comes to implementing an EW and managing DSS

15 emergencies, the usual choice for implementing an EWS on critical landslides based on the evaluation of a single threshold could easily lead to a "cry wolf" effect or, in the worst case, an over-reliance on a single method of assessment could lead to human losses if the method chosen does not take into account the actual geological, mechanical behavior and the rheology of the monitored slope.

20 2. Implementation of the Bayesian DSS to manage some active landslides in Valle d'Aosta: The Mont de La Saxe landslide DSS.

One of the main goals in designing a new and comprehensive DSS to manage the La Saxe EWS was to deal with the necessity to integrate quantitative and qualitative data in a clear and replicable process, without running the risk to lose any vital information.

25 The second goal was to obtain a numerical value of the PPV of the dispatched alerts in order to provide an objective value of the probability of the worst case scenario reached at any evaluation stage during the evolution of the landslide, i.e the confidence that all evidences, both qualitative and quantitative, provided to support the likelihood of the collapse event: $\mathrm{H}_{0}$.

The achievement of these results, with a transparent and replicable decisional process, would also have

30 an immediate and positive impact on the quality of the emergency communication to the population and to the other civil protection actors.

Due to the importance of the targets at stake, it was decided to design the main architecture of the DSS based on quantitative decisional values and to use the qualitative ones to only to strengthen the reliability of each single decisional step.

35 The overall architecture of the Bayesian inferential engine implemented at the Mont de La Saxe Landslide is shown in the conceptual model of Fig. 4 and the Table 1 reports the decisional values adopted.

The initial observed frequency (prevalence Pr) is set at 15\%, according to the assumptions made in the paragraph 1.1. The power of the Bayesian engine comes from the progressive increase of the "relative" prevalence of the phenomenon due to the relative increasing of Pr. 
Nat. Hazards Earth Syst. Sci. Discuss., https://doi.org/10.5194/nhess-2017-396

Manuscript under review for journal Nat. Hazards Earth Syst. Sci.

Discussion started: 30 November 2017

(c) Author(s) 2017. CC BY 4.0 License.

More in detail, an iterative process is performed, where the a posteriori Probability Density Function (or PDF) of the former step becomes the a priori PDF of the further test and the true value is progressively approached.

Note that some decisional values, the increasing of the water table in-depth level, are numerical

5 parameters objectively measurable. Despite that, these parameters do not have a robust statistical record to allow the evaluation of a numerical threshold. Moreover, these parameters are too linked to the behavior of the single phenomenon on which they are measured, i.e.: they are too site-specific.

The evaluation of these parameters is therefore maintained as quantitative, although the observation of some of them is important to sustain the decision to raise the alert condition to an upper level.

10 The Table 1, once transformed in a decisional tree (Fig. 5), shows more clearly the decisional process that allows the alert dispatching to the civil protection authorities.

Hence, another useful feature of the Bayesian DSS is that the iterative process allows the prediction of "intermediate stage scenarios" in case the process should not verify the $\mathrm{H}_{0}$. Thus it is possible to use the intermediate scenarios as outcomes of the DSS in the case $\mathrm{H}_{0}$ is not verified (Fig. 6). Note that $\mathrm{H}_{0}$ has to

15 be maintained as the null hypothesis during the whole decisional process. As a matter of fact, should $\mathrm{H}_{0}$ be changed during the evaluation process, the application of [3] will have to be adjusted due to the different $\mathrm{Sp}$ and Se values.

\section{Application of the DSS to the Brenva site rock-avalanche (Mont Blanc Massif, Italy)}

20 The above exposed DSS is now being applied on another site, the Brenva site. The site is a steep rocky wall located in the Mont Blanc Massif above the Brenva glacier on the Col Moore ridge southeastern flank (Fig. 7 and 8).

In this case the potential collapse of a large scale rockfall from the slope, could trigger a large ice-rock avalanche like the catastrophic one that happened in 1997 (Barla et al, 2000; Deline P., 2001; Deline P., 25 2009).

At this site, the implementation of an integrated monitoring system faces both environmental and logistical issues due to the site altitude (about $3.800 \mathrm{~m}$ a.s.1.), and low temperature conditions ( $\mathrm{T}$ ranging down to $-30{ }^{\circ} \mathrm{C}$ ). In such conditions the Regional geological survey was forced to install a monitoring system made by remote monitoring networks integrated by accelerometers placed to detect potential collapse forerunners.

Under those constraints, due to the relative lack of quantitative data, it was necessary to implement a DSS based mostly on qualitative decisional values. (Tab. 2)

The $\mathrm{H}_{0}$ (top event) in this case is a massive rockfall collapse having a volume $\mathrm{V}>1 * 10^{\circ} \mathrm{m}^{3}$ that could evolve as an ice-rock avalanche. Winter conditions with consistent snow cover are supposed to be a fundamental element to trigger such a phenomenon. The DSS implemented is therefore limited to the situation where a consistent snow cover is present and the rockfall volume is greater than $1 * 10^{\circ} \mathrm{m}^{3}$.

The parameters conditioning the decisional values ( $\mathrm{Pr}, \mathrm{Se}, \mathrm{Sp}$ ) are quite difficult to assess, because ice rock avalanche phenomena are quite uncommon and significant statistical records describing these phenomena are lacking. 
Nat. Hazards Earth Syst. Sci. Discuss., https://doi.org/10.5194/nhess-2017-396

Manuscript under review for journal Nat. Hazards Earth Syst. Sci.

Discussion started: 30 November 2017

(c) Author(s) 2017. CC BY 4.0 License.

For the first decisional step, where Pr is significant because it influences the Pr values of the further steps in the decisional chain, a Pr value $=15 \%$ could be accepted, according to the results by Malamud et al., (cit.) regarding the correlation between rockfalls frequency and their volume.

It should be noticed that, even with poor quantitative decisional values, a PPV of $85 \%$ is reached within

5 two decision steps inserting in the process quantitative but objective decisional values such as rockfall frequency increase and so on. Further observations and decisional values can be inserted into the DSS, in order to strengthen the reliability of the alerts. According to that, a recently activated local accelerometric sensing network will probably provide further decisional elements (Amitrano et al., 2010).

\section{Application of the DSS at the Lillianes site (Lys Valley)}

Lillianes is a small municipality located in the Lys Valley, in the southeastern zone of the Valle d'Aosta. On April 19" 2017 a rockfall collapse of about $70 \mathrm{~m}^{3}$, hit a municipal road. The geological inspection of the detachment zone highlighted the presence of a large unstable rock mass about having a

15 volume of about $250 \mathrm{~m}^{3}$. The odds of further collapses led to the precautionary closure of the road, isolating some villages, which hosted farms and touristic activities.

The time required by the construction of a new safer road and the necessity to allow the traffic on the older one led to the installation of a monitoring system on the unstable volume, aimed to detect the predictors of a likely collapse, by blocking the traffic circulation.

20 This time, the problem was to detect the collapse predictors on a relatively small rock volume. Small volume rockfalls are usually considered as difficult to monitor and to predict, due to the relative lack of predictors and the limited time interval between the detection of the predictors and the actual collapse, which strongly reduces the chances of implementing an effective civil protection procedure if it is based on a common single threshold DSS.

25 The necessity to dispatch reliable alerts in time to close the road led to the choice to implement an integrated monitoring network, consisting of a wire-extensometer (on site monitoring instrumentation) installed on the upper crack delimiting the rocky mass, and a robotized total station (RTS) for redundant remote monitoring, targeted at some prisms directly installed on the unstable volume (Fig. 9 and 10).

Since the collapses of large and massive rock volumes generally occur all of a sudden and involve the

30 whole unstable mass, some adjustments have been done to the DSS, suppressing the ordinary surveillance stage and choosing to directly activate the dispatch of the warnings in case of a positive assessment of the first decisional value.

The first decisional value is based on an absolute positive displacement of $5 \mathrm{~mm} /$ hour in one measurement cycle, measured by RTS on the Line Of Sight (LOS) that is, the RTS is employed as an extremely precise distometer. This displacement has to be confirmed by the second decisional value provided by the on site strain gauge displacement.

In implementing the DSS, the following values were set to determine the first decision value: $\operatorname{Pr}=15 \%$, $\mathrm{Se}=100 \%, \mathrm{Sp}=90 \%$. The high Sp value has been set because, although consistent statistical records are not available, it is reasonable to assume that a positive displacement of $5 \mathrm{~mm}$ of a massive rock

40 volume, if confirmed, is a reliable predictor of a true collapse in progress. In fact, as massive rock masses show brittle behavior, because they don't have structural discontinuities being able to absorb 
Nat. Hazards Earth Syst. Sci. Discuss., https://doi.org/10.5194/nhess-2017-396

Manuscript under review for journal Nat. Hazards Earth Syst. Sci.

Discussion started: 30 November 2017

(c) Author(s) 2017. CC BY 4.0 License.

great stresses, even the smallest acceleration can be assumed to be the predictor of an imminent collapse. The same assumptions can be done about the second decisional value that relies on the wireextensometer displacement (Tab. 3).

This circumstance immediately emphasizes another almost obvious feature of the DSS, consisting of the

5 possibility to combine two or more decisional values in one single stage, if required by the ongoing situation. That feature furtherly favors the safety of the civil protection system, reducing the delays in the decisional process, that leads to dispatch the civil protection alerts, if all the decisional values set for the decisional step are available at the same time. In other words, the decision-maker can switch directly from the dispatching of "warning" to "alert" or to "imminent collapse" messages.

\section{Useful aspects of the Bayesian DSS when applied to landslide hazard management}

\subsection{The problem of the threshold modification and the insights of the Bayesian method}

Coming back to the adoption of displacement thresholds in EWS, it has to be highlighted that, if a slope instability exceeding the $V_{24}$ threshold finally doesn't collapse, in the most common practice an analysis will be to undertaken, aimed to identify the causes which didn't lead to the final collapse. This analysis usually will adopt a deterministic approach and these causes will be likely ascribed to sitespecific rheological and structural factors.

As a matter of fact, one of the common outcomes of these post-event analyses is that, facing the experience of an unstable slope that exceeding the warning threshold and actually don't collapse, it is usually acknowledged that the mechanical properties of the landslide materials are better than formerly estimates and therefore the warning thresholds (e.g.: $\mathrm{V}_{24}$ ) have to be reviewed and raised to upper values.

These outcomes are usually adopted under the pressure by the public opinion, which is not prone to accept preventive civil protection measures, or for other reasons, last but not the least the so-called "confirmation bias" that could influence the experts (Kahneman and Tvertsky, cit., Klayman and Ha, 1987).

Confirmation bias leads the experts to behave to avoid changing their theory, even if robust clues about its fallacy actually arise. The reaction will usually consist in adapting the theory to the new situation, changing some little detail or parameter in order to maintain the overall architecture of the originally chosen model.

The Bayesian DSS approach suggests that the choice of changing the warning thresholds should be made very cautiously.

To do so, the "cut-off" process, a method that is adopted to evaluate the accuracy of medical tests, can explain the effects of changing of the threshold values.

35 Widely treated in medical literature, this kind of method uses the shifting of the mean value of a PDF in a "cut-off" process, that is derived from electronics, as a method to increase or decrease the sensitivity of receivers to minimize noise and emphasize the signals providing the "true" information (Parmigiani and Inoue, 2009).

To explain that, it could be assumed that the probability distribution function (PDF) of the displacement threshold has a common Gaussian distribution (it could be also another type of PDF). In the La Saxe 
Nat. Hazards Earth Syst. Sci. Discuss., https://doi.org/10.5194/nhess-2017-396

Manuscript under review for journal Nat. Hazards Earth Syst. Sci.

Discussion started: 30 November 2017

(c) Author(s) 2017. CC BY 4.0 License.

case the Mean Value of the PDF could be $V_{24}=2 \mathrm{~mm} / \mathrm{h}$ but, after the La Saxe 2013 and 2014 experience the displacement value of $\mathrm{V}_{24}=2 \mathrm{~mm} / \mathrm{h}$ has proven to be not true, i.e.: the landslide didn't collapse in the end.

Hence, performing a post-event analysis, the decision makers who rely on a single-decisional value method could make the most logical choice: to raise the value of the $\mathrm{V}_{24}$ threshold because it appears that the landslide materials have better mechanical properties than expected.

Under these assumptions there are two options, as shown in Fig. 11. The first one is to increase the $\mathrm{V}_{24}$ threshold $\left(\mathrm{X}_{1}\right)$ shifting it toward the real $\left(\mathrm{X}_{3}\right)$ value. This corresponds to raise the threshold value. As a result, cut-off of the false positives will be obtained (red area). At the same time, however, to approach

$10 \mathrm{X}_{3}$ means including the false negatives, dangerously increasing the probability of not detecting instabilities that are actually going to collapse. Moreover, the time available to enforce the civil protection plans will be dangerously reduced. All these drawbacks strongly suggest not increasing the threshold values unless there aren't strong site-specific evidences sustaining that choice.

On the other hand, decreasing the threshold value in favor of safety clearly increases the number of

15 false positives and the "cry wolf" effect, which is not acceptable for obvious reasons of reliability of the civil protection system.

The potential flaws and risks associated to the threshold manipulations can be mitigated with the Bayesian approach since it allows the decision makers to embed the $\mathrm{V}_{24}$ (or another threshold value) in an articulated DSS, and the global PPV provided by the Bayesian inferential engine will increase

20 without any need to modify the $\mathrm{V}_{24}$ threshold value.

It is worth to note that, if the number of the decisional values in the DSS is sufficient to achieve a satisfactory global PPV, the decision-makers will also be able to decrease the values of the first warning thresholds by adding other integrative decisional values that will be assumed when the warning threshold is exceeded. This operation, that can be done when the PDF of the decisional values are not well defined and maintains a conservative approach to the emergency management and ensuring at the same time the reduction of the false alerts.

\subsection{Taking advantage of the opportunities provided by the adoption of a Bayesian DSS}

Another useful feature of the Bayesian DSS coming from its properties is the opportunity to immediately add to the DSS new decisional values (new evidences and data), which could become available after the original architecture of the DSS has been implemented. This means that the Bayesian DSS is flexible and makes the decision makers able to rule evolving situations like the emergency ones. This is particularly evident in the evolutionary landslides that usually yield new qualitative morphological and structural terrain evidences that can be interpreted as signs of growing instability and thus worth to take into account in the decision process to sustain the issuing of alerts.

Furthermore, adding new decisional values improves the PPV of the alerts and strengthens the reliability of a DSS system.

The Mont de La Saxe landslide DSS can provide another example if one would implement the formerly explained DSS, evaluating the sensitivity of the landslide to rainfalls or storms. These kinds of large and 
Nat. Hazards Earth Syst. Sci. Discuss., https://doi.org/10.5194/nhess-2017-396

Manuscript under review for journal Nat. Hazards Earth Syst. Sci.

Discussion started: 30 November 2017

(c) Author(s) 2017. CC BY 4.0 License.

deep complex landslides usually are poorly sensitive to rainfalls and storms, unless these events last for several days. As a matter of fact, the experience of the Oct. $14^{\text {th }}-16^{\text {th }} 2000$ flooding showed that heavy rainfalls lasting more days have been able to triggered four slope instabilities (each one having a volume $\mathrm{V}>1 * 10^{6} \mathrm{~m}^{3}$ ) in Aosta Valley.

5 Thus the DSS for the Mont de La Saxe landslide can be modified to include the case of a meteorological warning for heavy rainfalls (cumulated rainfalls $>65 \mathrm{~mm} / 24 \mathrm{~h}$ ). In that case $\mathrm{H}_{0}$ is the collapse of the whole unstable slope during a heavy rainfall event.

The issuing of a meteorological warning for heavy rains by the regional meteorological office will be put in the DSS as the first decisional value of the process. If a meteorological warning is issued, the first

10 decisional value will have a PPV of about $34,5 \%$, assuming $\operatorname{Pr}=5 \%, \mathrm{Se}=100 \%, \mathrm{Sp}=0,90$. Note that the Pr value is assumed as a low, due to the small percentage of deep landslides which have been historically activated by heavy rainfalls in the Region, $\mathrm{Se}=100 \%$ due to the logical assumption that the landslides that are collapsing under $\mathrm{H} 0$ are all triggered by heavy rainfalls, Sp is $90 \%$ due to the high precision of the weather forecasts when a well structured cyclonic situation is expected (with two or

15 three days of advance).

Acting in this way the $\mathrm{V}_{24}$ threshold assumes another meaning, because it becomes a second level decisional value, with a $P P V=72,5 \%$. It is easy to note that the exceeding of $V_{24}$ threshold in a heavy rain condition assumes a completely different meaning in terms of incumbent hazard and what is almost a common sense consideration, can be now mathematically sustained.

20 Figure 12 shows how the confidence curve is being shifted increasing the predictability of $\mathrm{H}_{0}$ by the addition of a new decisional values such as a weather alert, strengthening the reliability of the civil protection alerts that can be made compliant to the requirements set by the Italian Civil Department directives (Italian Civil Protection Department, 2004).

\section{Conclusions-Discussion}

The monitoring experience led during the emergency of the Mont de La Saxe landslide in 2013 and 2014 made it possible to codify and implement a replicable method that has been, so far, successfully applied to other critical situations too.

The elaborated multistage decision support system is, nowadays, under testing on a growing number of 30 instabilities in Aosta Valley and the results are encouraging.

However, at a first glance, the method proposed could seem a less conservative method compared to the traditional ones, a method which could lead experts and public officers to delay critical decisions while they search further supporting elements, thus wasting useful time in adopting emergency measures and, ultimately, taking more risks.

35 Despite that, as highlighted in the paragraph 5.1, it should be taken into account that a stiff numerical method, relying only on numerical thresholds to dispatch alerts, even though it seems more conservative and objective, could produce exactly the opposite effect.

Furthermore, decision-makers adopting a single threshold method could easily underestimate the new information coming from quantitative sources (e.g.: new monitoring systems put online in the 
Nat. Hazards Earth Syst. Sci. Discuss., https://doi.org/10.5194/nhess-2017-396

Manuscript under review for journal Nat. Hazards Earth Syst. Sci.

Discussion started: 30 November 2017

(c) Author(s) 2017. CC BY 4.0 License.

monitoring network) or qualitative ones (e.g.: observation of new fractures on a monitored unstable slope), just because they have to "comply the protocol".

On the other hand, a multi-stage DSS allows the addition of new elements if the alert level has not been reached; thanks to this feature the decision maker is able, at any time, decide to dispatch an alert if he thinks to have gathered a consistent number of critical elements.

Moreover, for which regards the assessment of $\operatorname{Pr}$ and $\mathrm{Sp}$ values, it can be noticed that an accurately calibration of their values It is not so relevant to improve the reliability of a DSS, even though that is always a good achievement.

Rather, the effectiveness of a DSS depends more on the availability of a sufficient number of decisional

10 values, which can improve the global PPV of the DSS. The latter evidence makes the Bayesian DSS a powerful tool to assume critical decision where, as in the Brenva case, a sufficient set of numerical data will be unavailable due to objective hurdles.

In other words, the addition of new qualitative or quantitative decisional value can compensate for the lack of accuracy in determining the correct value of Pr or Sp.

15 This is quite an intuitive procedure, since it is the basis of the investigative method. Unfortunately, what almost a common sense procedure, seems to be widely underestimated in the implementation of DSS for which regards the landslides, often in favor of systems which are more focused on predicting the ToF, rather than issuing reliable warnings. In the light of a Bayesian DSS, the search for an even sharper assessment of the ToF is a false issue, because for example, when a PPV of $99 \%$ is reached, the collapse will be anyway imminent.

To deal with the subject from an operational point of view, another advantage of adopting a Bayesian DSS is that it allows to set general criteria to design the monitoring networks, giving instructions to the EWS planners on how to choose the instruments on the basis of the parameters that effectively are suitable to feed the Bayesian inferential engine and the DSS.

25 Therefore, the installation of useless and redundant instrumentation can be avoided with savings in purchasing expenses, maintenance and, last but not least, increasing operators' safety because unstable slopes are usually a hazardous environment.

Even the spatial configuration of the monitoring networks (e.g.: the location of the RTS targets or GPS on-site receivers) will benefit from this kind of approach, leading it to a more effective spatial layout of

30 the monitoring instruments, avoiding redundancies and a wrong placements of the instruments.

As shown in the studied cases, simpler phenomena could require simpler networks and the integration of qualitative decision values in the DSS will strengthen its reliability once that they will be easily gathered.

The traditional and widely adopted models, which make use of early warning empirical thresholds,

35 suffer the lack of a consistent historical back analysis record.

As before highlighted, a considerable amount of studies are focused on the assessment of EW thresholds and actually rely on back analyses that forcefully include a great percentage of actually collapsed unstable slopes.

That kind of flaw, which biases these statistical analyses, is unavoidable because the historical records

40 usually only include the catastrophic phenomena which were monitored for their extreme activity and, at the same time, potential catastrophic phenomena which didn't yet collapse are being monitored only 
Nat. Hazards Earth Syst. Sci. Discuss., https://doi.org/10.5194/nhess-2017-396

Manuscript under review for journal Nat. Hazards Earth Syst. Sci.

Discussion started: 30 November 2017

(c) Author(s) 2017. CC BY 4.0 License.

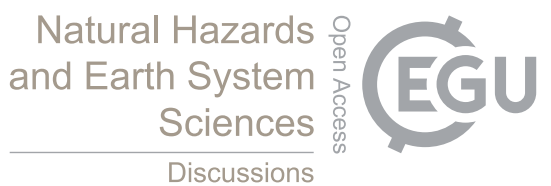

since a few decades thanks to the development of the natural hazard culture and to the increasing availability of cheaper and more reliable instruments.

These assumptions make it likely to expect that, in the near future, with the aid by stronger statistical records, Sp and Pr will become more reliable, as an increasing number of cheaper and widespread

5 monitoring networks are nowadays being installed on many unstable slopes all over the world.

On the other side, the development of more detailed landslide inventories, that will be better calibrated on the type of phenomenon in a restricted area (that is: area-specific), will probably provide more accurate values of Pr, allowing a more precise assessment of the PPV. As a matter of fact, as shown before, the correct estimation of the Pr value is the real critical point to calibrate the Bayesian inferential

10 engine that supports the DSS.

Under this light, the ongoing implementation of the PS Journals, allowing the monitoring of large earth regions at an high spatial and temporal resolution will provide the real key instrument to assess the Pr of instabilities at the desired scale.

To do that it will be necessary to achieve a more operational classification of landslides, abandoning the

15 classic naturalistic classifications based on geomorphological evidences and adopting a more quantitative definition of landslide.

For instance, Pr value could be better calculated if, to define a landslide a definition like the following have been adopted: landslide is an unstable slope whose velocity is not compatible with human activities as it puts them at risk or compromises, directly or indirectly.

20 A definition like that allows the emergency managers to directly use the approaches like the one by Cruden and Varnes (1996), where the landslide management is seen under a dynamic approach, based on the displacement velocity, hence bringing back all the landslide monitoring topic under a quantitative framework.

At the same time, as a general remark, It is worth to note that the increasing availability of numerical

25 open data useful for landslide EWS, such as satellite InSAR technologies, is a benefit that could be easily overthrown, if the collection of these data will not be embedded into a correct decision-support process, that's because, as in happen in medicine, they are probably the first true screening systems that have ever been available for geohazard prevention.

\section{References}

Amitrano D., Arattano M., Chiarle M., Mortara G., Occhiena C., Pirulli M., Scavia C.: Microseismic activity analysis for the study of the rupture mechanisms in unstable rock massess. Nat. Hazards Earth Syst. Sci., 10, 831-841, https://doi.org/10.5194/nhess-10-831-2010, 2010.

Barla G., Dutto F., Mortara G.: Brenva glacier rock avalanche of 18 January 1997 on the Mont Blanc range, northwest Italy. Landslide News 13: 2-5, 2000.

Bayes T.: An essay towards solving a problem in the doctrine of chances," Philosophical Transactions of the Royal Society, Volume 53, Issue 1, pp. 370-418, 1763.

Bertolo D.: Frana del Mont de La Saxe in Comune di Courmayeur, Nota tecnica sullo stato del fenomeno sulla base delle esperienze gestionali maturate alla data del 03 giugno 2013. Unpublished technical report (in Italian), 2013. 
Nat. Hazards Earth Syst. Sci. Discuss., https://doi.org/10.5194/nhess-2017-396

Manuscript under review for journal Nat. Hazards Earth Syst. Sci.

Discussion started: 30 November 2017

(c) Author(s) 2017. CC BY 4.0 License.

Bertolo D.: Early warning et grands glissements de terrain - vers une nouvelle approche du problème. Les expériences récentes et l'évolution future. Unpublished lecture. Université Européenne d'Eté sur les Risques Naturels - octobre 2014. Risque induit par les ruptures de barrages et les vidanges de poches d'eau en altitude dans un contexte de changement climatique. Module 6c: Surveillance - alerte. Vallée 5 de Gressoney (Vallée d'Aoste-Italie), 2014.

Bertolo, D.: The Mont de La Saxe Landslide (Valle d'Aosta-Italy) - Evolution a large alpine landslide controlled by different hydrogeological components. Conference paper. $4^{\text {th }}$ Slope tectonics conference. Kyoto, 13-14 Oct. 2017, 2017.

Calvello M.: Early warning strategies to cope with landslide risk. Rivista italiana di geotecnica 2/2017, 2017. Doi:10.19199/2017.2.0557-1405.063, 2017.

Crosta, G.B., Agliardi, F.: Failure forecast for large rock slides by surface displacement measurements. Canadian Geotechnical Journal, 40, 176-191, 2003.

Crosta G.B., Castellanza R., Frattini P., Broccolato M., Bertolo D., Cancelli P., Tamburini A. Comprehensive understanding of a rapid moving rockslide: the Mt de la Saxe landslide.: Conference 15 paper. MIR 2012 XIV Ciclo di Conferenze di Meccanica e Ingegneria delle Rocce-Nuovi metodi di indagine, monitoraggio e modellazione degli ammassi rocciosi, 20 pp, 2012.

Cruden, D.M., Varnes, D.J.: Landslide types and processes. In: Turner, A.K., Schuster, R.L. (Eds.), Special Report 247 Landslides: Investigation and Mitigation, 1996.

Deline, P.: Recent Brenva rock avalanches (Valley of Aosta): New chapter in an old story?, Geogr. Fis.

Din. Quat., 5, 55-63, 2001.

Deline, P.: Interactions between rock avalanches and glaciers in the Mont Blanc massif during the late Holocene. Quaternary Science Reviews 28: 1070-1083, 2009.

Di Biagio E., Kjekstad O.: Early Warning, Instrumentation and Monitoring Landslides. Proc. 2nd in Regional Training Course, Reclaim II, Phuket, Thailand, pp. 18-21, 2007.

25 Dixon-Woods M, Agarwal S, Jones D, Young B., Sutton A.: Synthetizing qualitative and quantitative evidence: A review of possible methods. J Health Serv Res Policy; 10:45-53, 2005.

Dunnicliff J.: Geotechnical Instrumentation for Monitoring Field Performance. John Wiley and Sons Ed., ISBN: 978-0-471-00546-9. 608 pp., 1994.

Fukuzono, T.: A new method for predicting the failure time of a slope. Proc. IV International Conference and Field Workshop on Landslides, Tokyo, 1985.

Giardino M., Ratto S.: Analisi del dissesto da frana in Valle d'Aosta. In: rapporto sulle frane in Italia APAT Rapporti, 78/2007:121-150, 2007.

Giordan, D., Manconi, A., Allasia, P., and Bertolo, D.: Brief Communication: On the rapid and efficient monitoring results dissemination in landslide emergency scenarios: the Mont de La Saxe case study. Nat. Hazards Earth Syst. Sci., 15, 2009-2017, https://doi.org/10.5194/nhess-15-2009-2015, 2015.

Kahneman D. and Twersky A.: Prospect theory: an analysis of decision under risk. Econometrica. Vol. 47, No. 2 pp. 263-292. doi:10.2307/1914185, 1979. 
Nat. Hazards Earth Syst. Sci. Discuss., https://doi.org/10.5194/nhess-2017-396

Manuscript under review for journal Nat. Hazards Earth Syst. Sci.

Discussion started: 30 November 2017

(c) Author(s) 2017. CC BY 4.0 License.

Kahneman D.: Thinking fast and slow. Farrar, Straus and Giroux Ed.. ISBN:978-0374275631, 2011.

Klayman, J. and Ha, Y-W. Confirmation, Disconfirmation and information in hypothesis testing. Psychological Review, American Psychological Association, 94 (2): 211-28, doi:10.1037/0033295X.94.2.211, 1987.

5 Malamud B., Turcotte D.L., Guzzetti F., Reichembach P.: Landslide inventories and their statistical properties. Earth Sciences Processes and Landforms, 29, 687-711, 2004.

Manconi A., and Giordan D.: Landslide early warning based on failure forecast models: the example of the Mt. de La Saxe rockslide, northern Italy, Nat. Hazards Earth Syst. Sci., 15, 1639-1644, 2015.

Mazzanti, P., Bozzano, F., Cipriani, I., and Prestininzi, A.: New insights into the temporal prediction of

10 landslides by a terrestrial SAR interferometry monitoring case study, Landslides, 12, 55 - 68, doi:10.1007/s10346-014-0469-x, 2015.

Medina-Cetina, Z., and Nadim F.: Stochastic design of an early warning system. Georisk Assess. Manag. Risk Eng. Syst. Geohazards, 2(4), 223-236, doi:10.1080/17499510802086777, 2008.

Michoud C., Bazin S., Blikra L. H., Derron M.-H., and Jaboyedoff M.: Experiences from site-specific

15 landslide early warning systems. Nat. Hazards Earth Syst. Sci., 13, 2659-2673, 2013. doi:10.5194/nhess-13-2659-2013, 2013.

Neyman, J, Pearson, E. S.: On the problem of the most efficient tests of statistical hypotheses. Philosophical transactions of the Royal Society A. 231 (694-706): 289337. doi:10.1098/rsta.1933.0009, 1933.

20 Parmigiani G., Inoue L.: Decision Theory: Principles and Approaches. John Wiley \& Sons. 402 pp., 047074667X, ISBN: 97804707466772009, 2009.

Peck, R. B.: Advantages and limitations of the observational method in applied soil mechanics. Géotechnique, 19 (2), 171-187., 1969.

Pulford, B. D., and Colman, A. M.: Overconfidence, base rates, and outcome positivity/negativity of predicted events. British Journal of Psychology, 87, 431-445. 1996.

Presidenza del Consiglio dei Ministri, Dipartimento della Protezione Civile, Direttiva: Indirizzi operativi per la gestione organizzativa e funzionale del sistema di allertamento nazionale, statale e regionale per il rischio idrogeologico ed idraulico ai fini di protezione civile. Gazzetta Ufficiale della Repubblica Italiana (in Italian), 11.03.2004, n.59. 2004.

30 Rose, N.D. and Hungr O.: Forecasting potential rock slope failure in open pit mines using the inversevelocity method. Int. Jour. Rock Mechanics \& Min. Science, 44, 308-320. doi:10.1016/j.ijrmms.2006.07.014, 2007.

Rothman K.J.: Epidemiology: an introduction. Oxford University Press. p. 53. ISBN 978-0-19-9754557, 2012.

35 Tamburini A. and Martelli D.: Displacement and rainfall threshold values for large landslide forecast in real time: the example of the "Becca di Nona" Landslide (Aosta). Conference Paper. Projet Interreg III 
Nat. Hazards Earth Syst. Sci. Discuss., https://doi.org/10.5194/nhess-2017-396

Manuscript under review for journal Nat. Hazards Earth Syst. Sci.

Discussion started: 30 November 2017

(c) Author(s) 2017. CC BY 4.0 License.

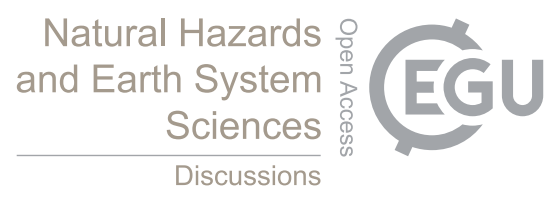

A ALCOTRA n ${ }^{\circ} 179$ (ex n46): "Risques hydrogéologiques en montagne: parades et surveillance RiskYdrogeo ". Saint Vincent, Italy, 2006.

Terzaghi, K.: Mechanisms of landslides. Applications of geology to engineering practice. Geol. Soc. Amer. Spec. Pub., Berkey Volume, 83- 123. 1950.

5 Voight B.: Material science law applies to time forecast of slope failure. Landslides news, 3, 1988.

Voight, B.: A relation to describe rate-dependant material failure. Science, 243, 200-203, 1989.

Voils C., Hasselblad V.: A Bayesian method for the synthesis of evidence from qualitative and quantitative reports: the example of antiretroviral medication adherence. J Health Serv Res Policy.14 (4): 226-233. doi:10.1258/jhsrp.2009.008186, 2009. 
Nat. Hazards Earth Syst. Sci. Discuss., https://doi.org/10.5194/nhess-2017-396

Manuscript under review for journal Nat. Hazards Earth Syst. Sci.

Discussion started: 30 November 2017

(c) Author(s) 2017. CC BY 4.0 License.

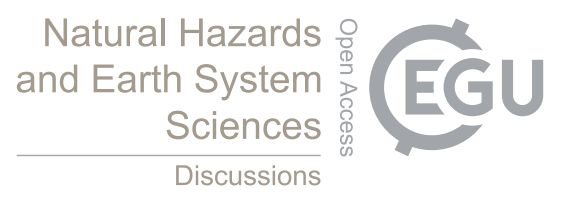

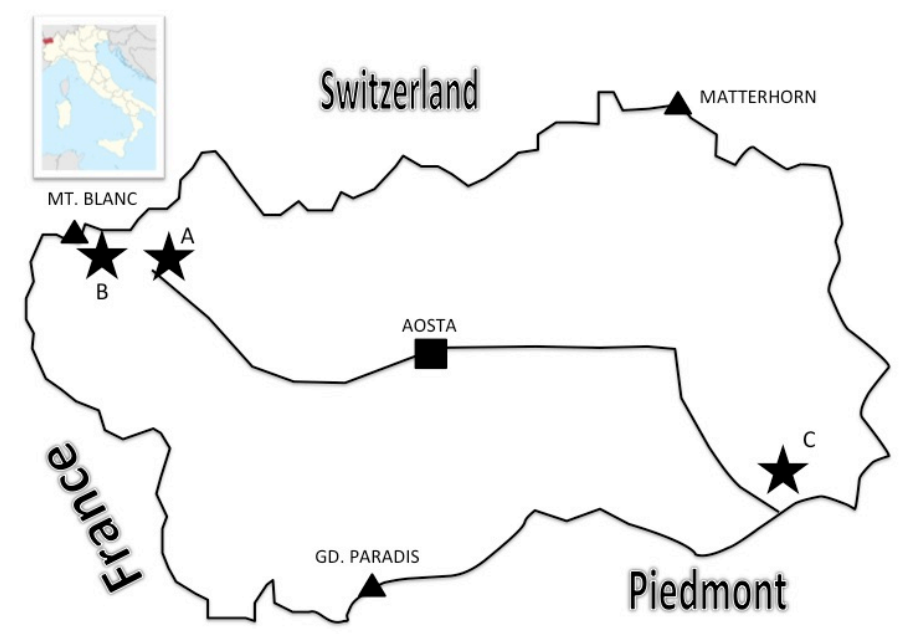

Figure 1. Schematic map of the Valle d'Aosta Autonomous Region. with the location of the site where the DSS has been implemented and tested. A: Mont de la Saxe landslide. B: Brenva rockslide and ice-rock avalanche. C: Lillianes rockfall.

5

10

15 
Nat. Hazards Earth Syst. Sci. Discuss., https://doi.org/10.5194/nhess-2017-396

Manuscript under review for journal Nat. Hazards Earth Syst. Sci.

Discussion started: 30 November 2017

(c) Author(s) 2017. CC BY 4.0 License.
Natural Hazards
and Earth System
Sciences
Discussions

(c) (1)

5
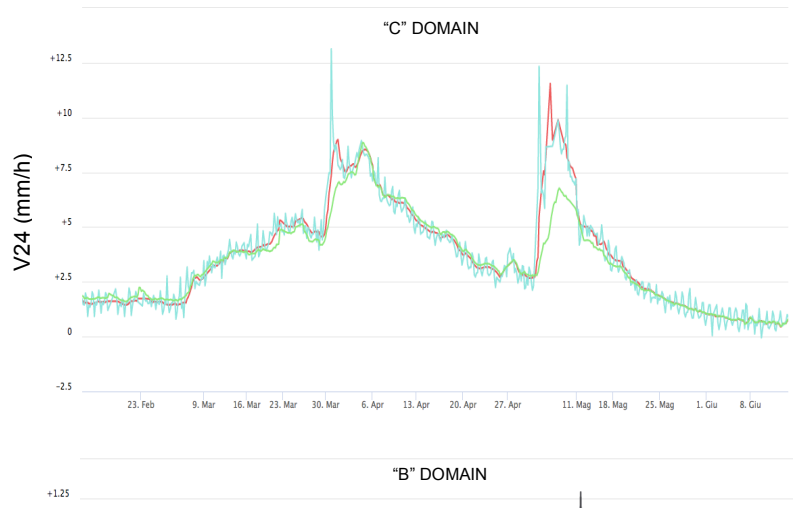

10

15

20

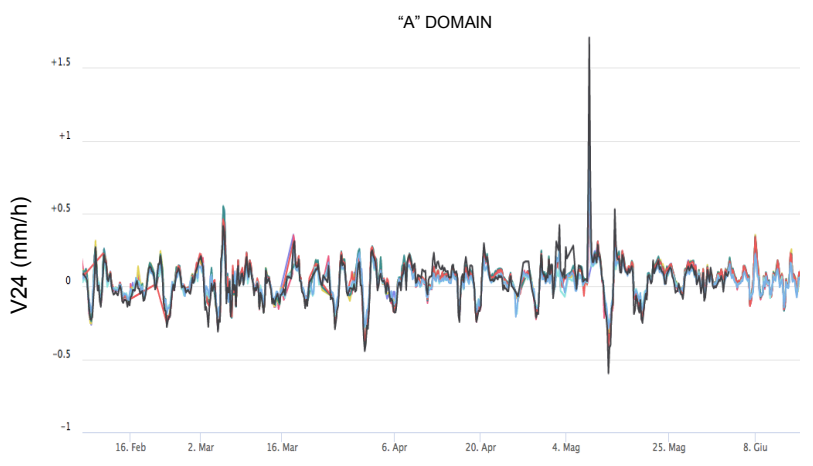

25

$\stackrel{\leftrightarrow}{>}$

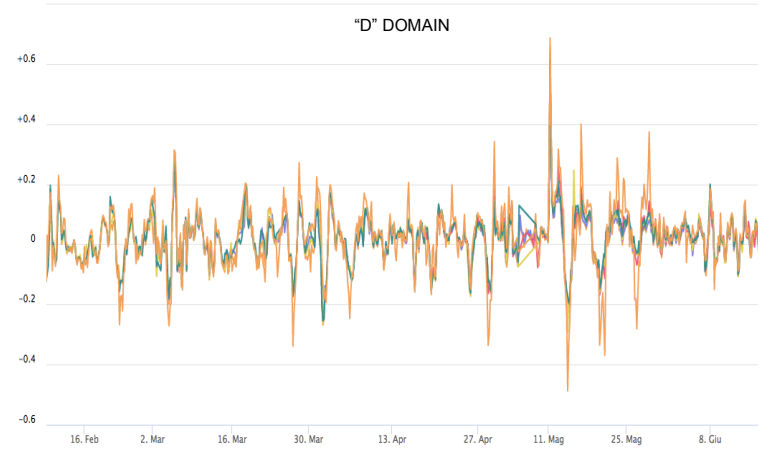

Figure 2. Example of the recall effect induced by the collapse of an active domain on the surrounding domains at the Mont de La Saxe site (upper right photo). The dashed yellow line marks the boundary of the unstable slope. The continuous yellow lines mark the cinematic 35 domains. The collapsed $\mathrm{C}$ domain is easily identifiable by the scarp. The graphs (below) show the velocities measured by the RTS network on the targets on the active domain (C) and in the surrounding domains (B, A, D) during the seasonal activations of 2015 (15.05.2015-1006.2015). It's immediate to note the intense recall effect on the upper hanging $B$ domain, strongly destabilized by the acceleration of the $C$ domain, which could evolve in a multiple sequential failure event (domino effect). The acceleration in the nearby domains is used as a decisional value in the La Saxe DSS. 
Nat. Hazards Earth Syst. Sci. Discuss., https://doi.org/10.5194/nhess-2017-396

Manuscript under review for journal Nat. Hazards Earth Syst. Sci.

Discussion started: 30 November 2017

(c) Author(s) 2017. CC BY 4.0 License.

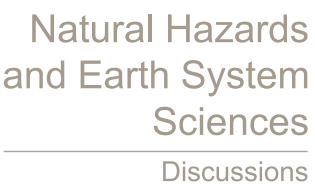

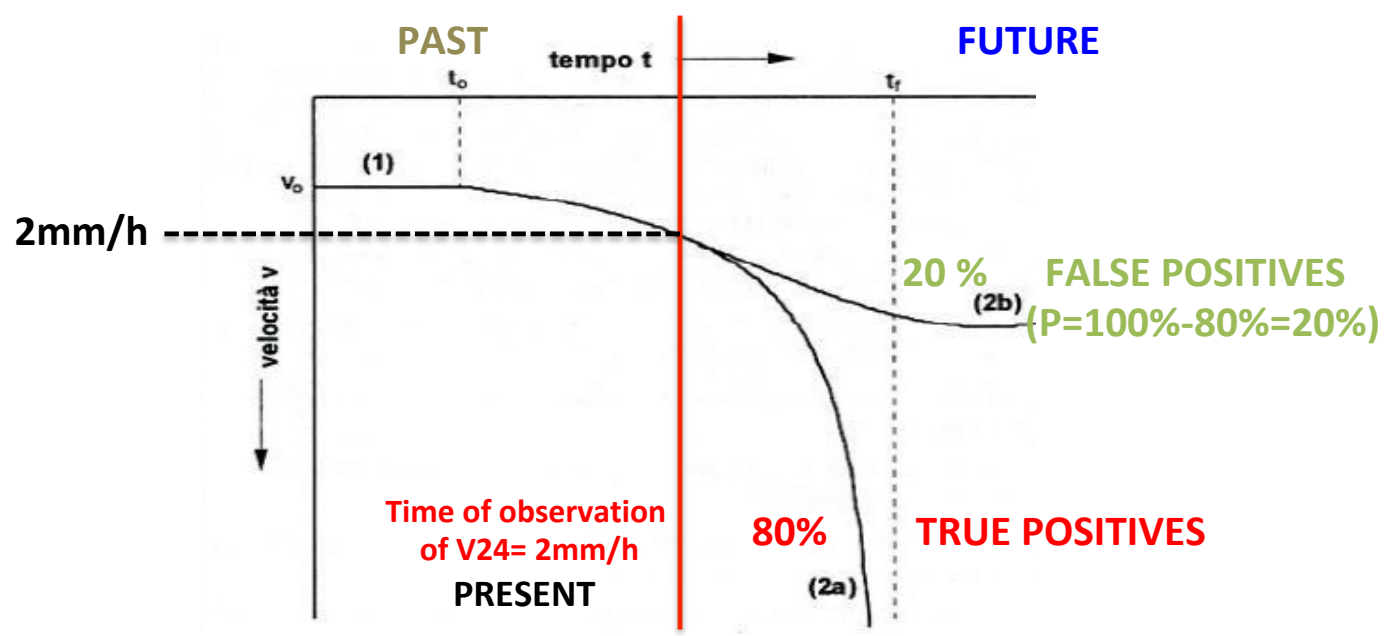

Figure 3. The $\mathrm{V}_{24}$ threshold (red line) and the possible behaviour of an unstable slope after the observation of the $\mathrm{V}_{24}$ exceeding (modified from Tamburini and Martelli, 2006). The path (2a) leads to the collapse, whilst the (2b) is a "false positive" one.

5

INFORMATION

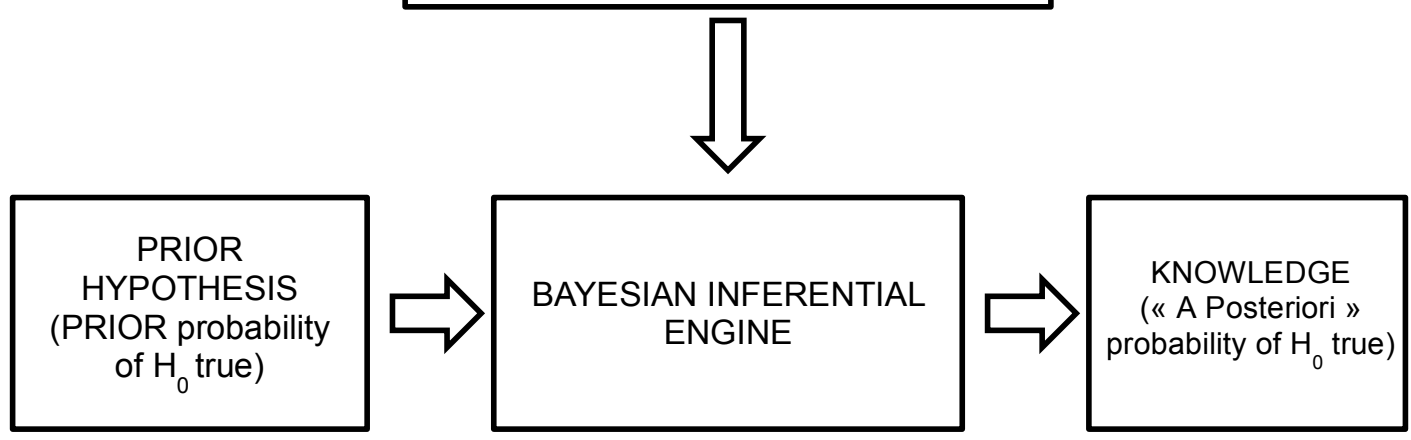

Figure 4. Conceptual model of a Bayesian inferential engine. 
Nat. Hazards Earth Syst. Sci. Discuss., https://doi.org/10.5194/nhess-2017-396

Manuscript under review for journal Nat. Hazards Earth Syst. Sci.

Discussion started: 30 November 2017

(c) Author(s) 2017. CC BY 4.0 License.

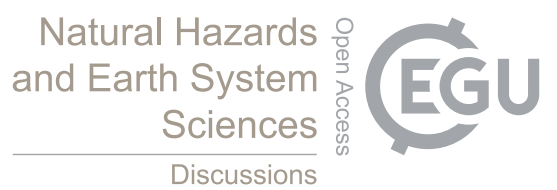

\begin{tabular}{|c|c|c|c|c|c|c|}
\hline WARNING LEVEL & $\begin{array}{c}\text { MAIN } \\
\text { DECISIONAL } \\
\text { VALUES }\end{array}$ & $\begin{array}{c}\text { SUPPORTING } \\
\text { DECISIONAL } \\
\text { VALUES } \\
\text { (QUALITATIVE) }\end{array}$ & PR & SE & SP & PPV \\
\hline ORDINARY MONITORING & $\begin{array}{l}\text { Displacement rate } \\
\mathrm{V}_{24} \text { under } 2 \mathrm{~mm} / \mathrm{h}\end{array}$ & - & - & - & - & - \\
\hline $\begin{array}{c}\text { INCREASED } \\
\text { SURVEILLANCE }\end{array}$ & $\begin{array}{ll}\mathrm{V}_{24}>2 & \mathrm{~mm} / \mathrm{h} \\
\text { measured } & \text { on a } \\
\text { restricted } & \text { spatial } \\
\text { domain } & \end{array}$ & - & $15 \%$ & $100 \%$ & $80 \%$ & $47 \%$ \\
\hline WARNING & $\begin{array}{l}\text { - } \mathrm{V}_{24}>2 \mathrm{~mm} / \mathrm{h} \\
\text { measured on a } \\
\text { significant and wide } \\
\text { spatial domain } \\
\text { - Displacement on } \\
\text { the failure plain } \\
\text { (detected by DMS) } \\
\text { exceeding } 10 \\
\text { mm/day; }\end{array}$ & $\begin{array}{l}\text { - Increasing trend of } \\
\mathrm{V}_{24} \text {; } \\
\text { - Increase of thermal } \\
\text { zero altitude above } \\
1600 \mathrm{~m} \text { a.s.l. }\end{array}$ & $47 \%$ & $100 \%$ & $80 \%$ & $82 \%$ \\
\hline ALERT & $\begin{array}{l}\mathrm{V}_{24}>2 \mathrm{~mm} / \mathrm{h} \\
\text { measured in the } \\
\text { surrounding sectors } \\
\text { of the unstable slope }\end{array}$ & $\begin{array}{l}\text { Increasing of the } \\
\text { water table in-depth } \\
\text { level; } \\
\text { - Increase of thermal } \\
\text { zero altitude above } \\
2300 \mathrm{~m} \text { a.s.l. }\end{array}$ & $82 \%$ & $100 \%$ & $80 \%$ & $96 \%$ \\
\hline IMMINENT COLLAPSE & $\begin{array}{l}\text { Increase in the } \\
\text { frequency of small } \\
\text { rockfalls (detected by } \\
\text { automatic rockfall } \\
\text { counter) }\end{array}$ & - & $96 \%$ & $100 \%$ & $80 \%$ & $99,1 \%$ \\
\hline
\end{tabular}

Table 1. Table showing the decisional values in the Mont de La Saxe Landslide DSS. 
Nat. Hazards Earth Syst. Sci. Discuss., https://doi.org/10.5194/nhess-2017-396

Manuscript under review for journal Nat. Hazards Earth Syst. Sci.

Discussion started: 30 November 2017

(c) Author(s) 2017. CC BY 4.0 License.

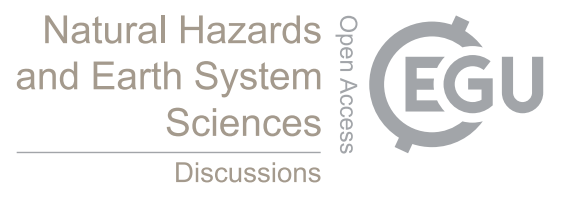

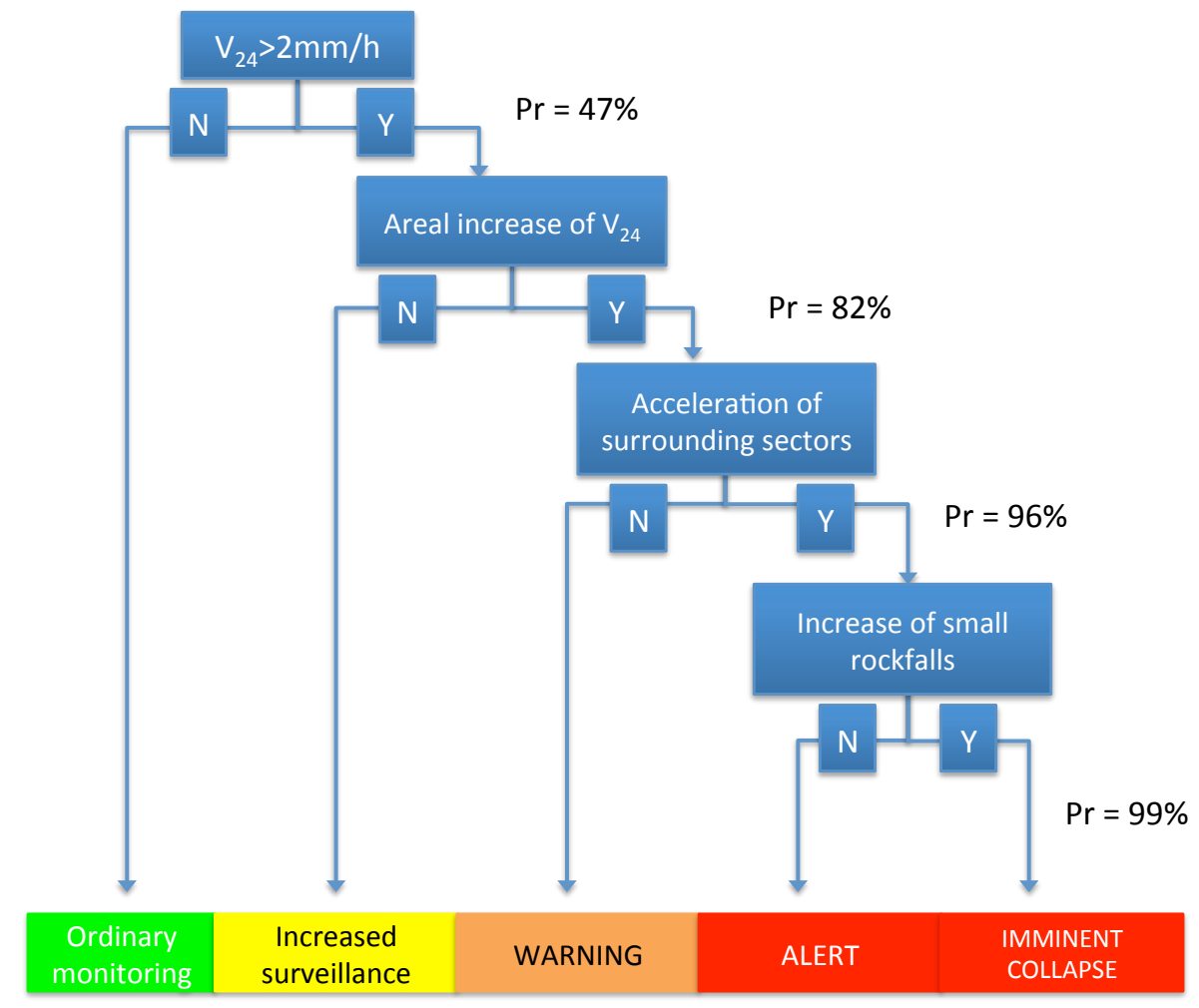

Figure 5. Decisional tree derived from Tab.. 5. 
Nat. Hazards Earth Syst. Sci. Discuss., https://doi.org/10.5194/nhess-2017-396

Manuscript under review for journal Nat. Hazards Earth Syst. Sci.

Discussion started: 30 November 2017

(c) Author(s) 2017. CC BY 4.0 License.

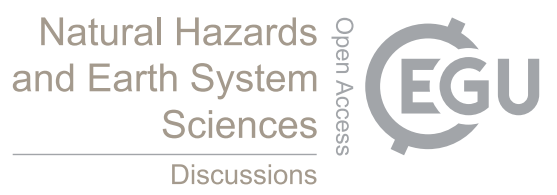

(c) (i)

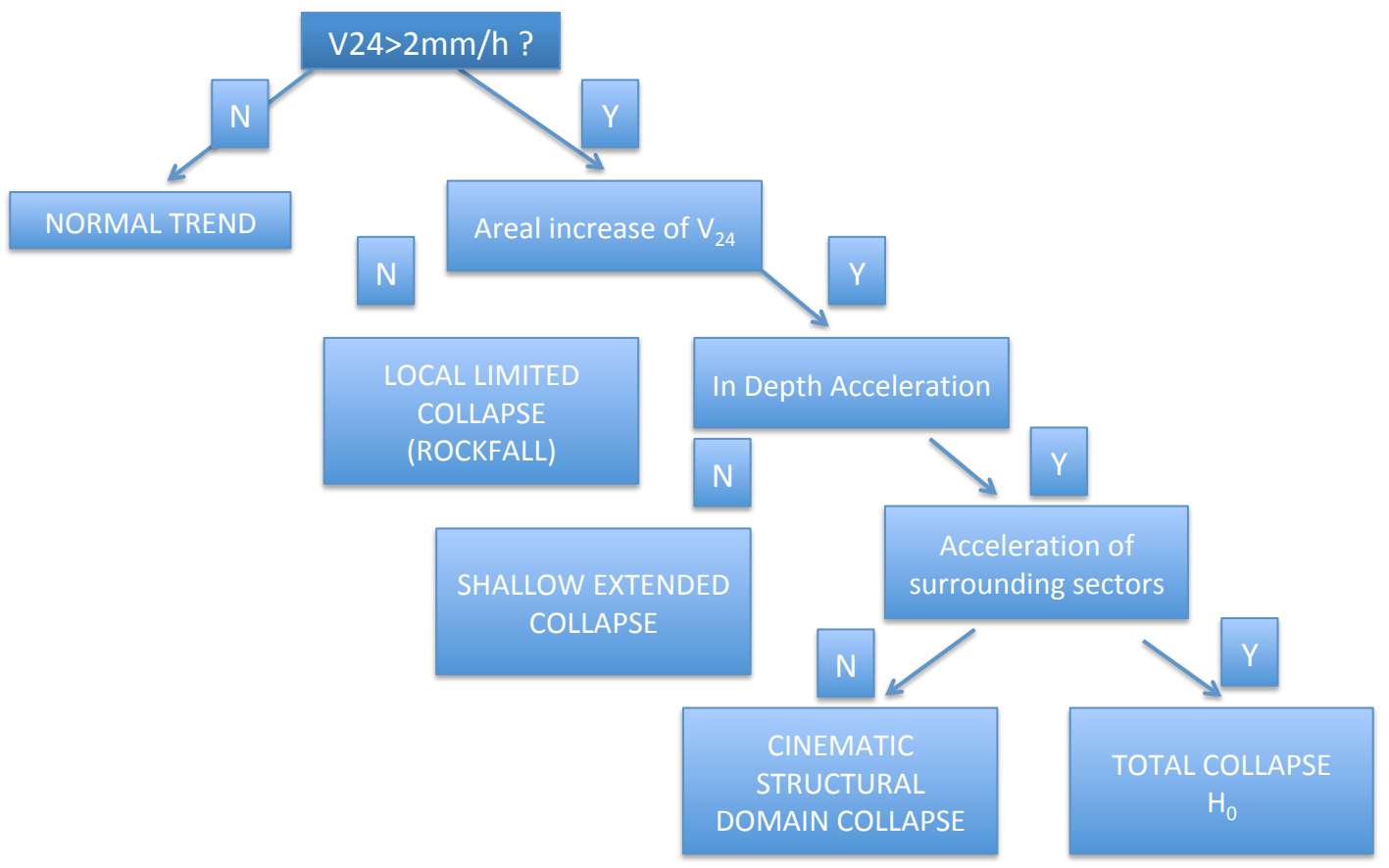

Figure 6. The decisional tree allows to select the most likely event scenario at any decisional step. At the first stage, all the scenarios have 5 the same probability to happen, the sequential iteration of the Bayesian DSS allows discarding the different scenarios when the decisional values aiming to the most likely scenario are positively verified. 
Nat. Hazards Earth Syst. Sci. Discuss., https://doi.org/10.5194/nhess-2017-396

Manuscript under review for journal Nat. Hazards Earth Syst. Sci.

Discussion started: 30 November 2017

(c) Author(s) 2017. CC BY 4.0 License.

\section{Natural Hazards and Earth System Sciences \\ Discussions}

5

10

15

Figure 7. The Col Moore ridge and the unstable slope hanging on the Brenva glacier as of Sept $30^{\text {th }}, 2016$ (photo: D. Bertolo, 2016) after a sequence of rockfalls that fed the fresh talus slope at the wall base. The potential unstable mass has a volume of at least $1 * 10^{6} \mathrm{~m}^{3}$ and is still under study.

Figure 8. Panoramic view of the Brenva glacier from Mont de La Saxe ridge. The red circle A) marks the detachment zone of Fig. 7. The red arrows downstream show the ice-rock avalanche path, whose cloud could endanger the traffic at the Southern gate of the Mont Blanc Tunnel (B). Photo: P. Thuegaz, 20

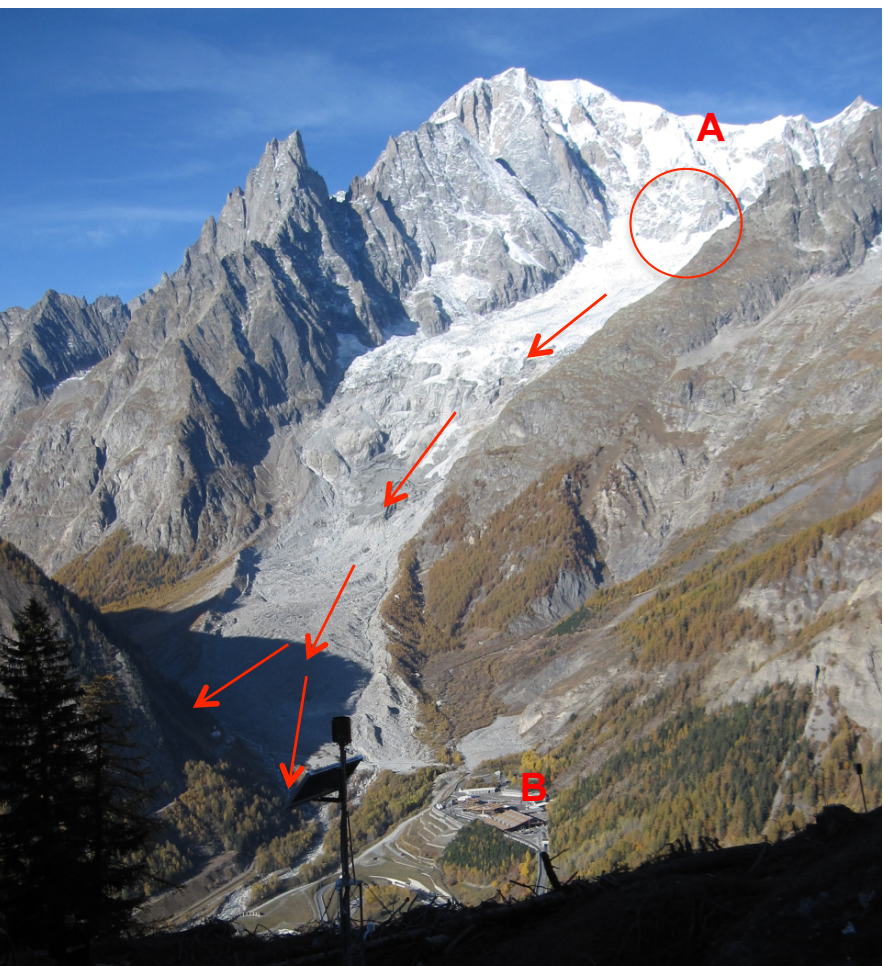

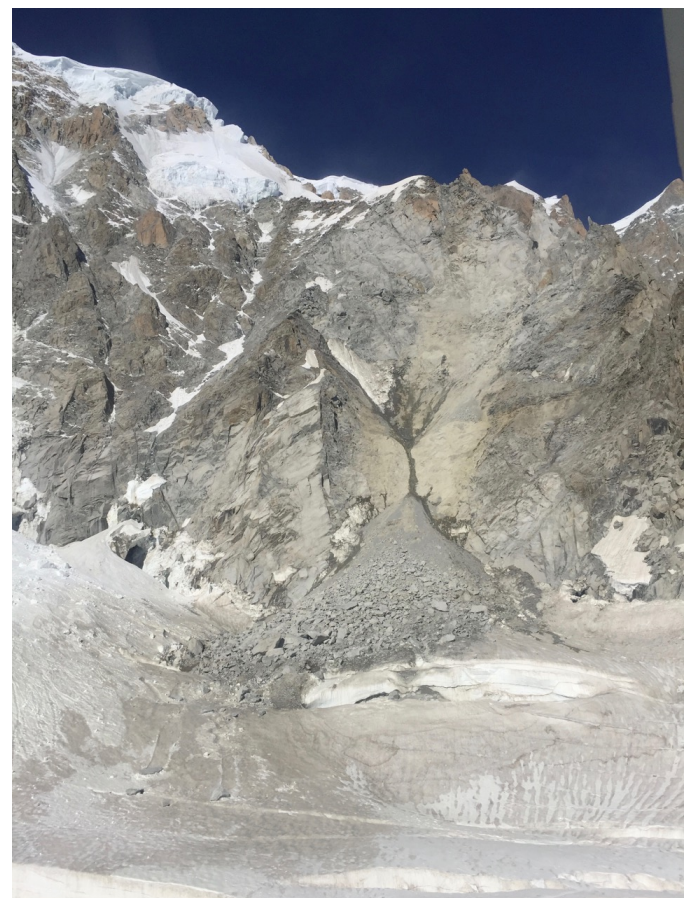


Nat. Hazards Earth Syst. Sci. Discuss., https://doi.org/10.5194/nhess-2017-396

Manuscript under review for journal Nat. Hazards Earth Syst. Sci.

Discussion started: 30 November 2017

(c) Author(s) 2017. CC BY 4.0 License.

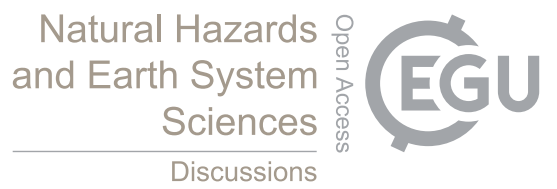

\begin{tabular}{|c|c|c|c|c|c|c|}
\hline WARNING LEVEL & $\begin{array}{c}\text { MAIN } \\
\text { DECISIONAL } \\
\text { VALUE (DV) }\end{array}$ & $\begin{array}{c}\text { SUPPORTING } \\
\text { DECISIONAL VALUES } \\
\text { (QUALITATIVE) }\end{array}$ & $\operatorname{Pr}$ & Se & Sp & PPV \\
\hline ORDINARY MONITORING & $\begin{array}{l}\text { Ordinary mountain } \\
\text { rockfall frequency }\end{array}$ & - & - & - & - & - \\
\hline $\begin{array}{c}\text { INCREASED } \\
\text { SURVEILLANCE }\end{array}$ & $\begin{array}{l}\text { Increase of rockfall } \\
\text { frequency from the } \\
\text { slope }\end{array}$ & - & $15 \%$ & $100 \%$ & $50 \%$ & $26 \%$ \\
\hline WARNING & $\begin{array}{l}\text { Rockfalls are } \\
\text { detected along } \\
\text { failures of a } \\
\text { possible } \\
\text { detachment zone } \\
\text { (delimiting a rock } \\
\text { volume }>1 \mathrm{Mm}^{3} \text { ) }\end{array}$ & Thick snowcover; & $26 \%$ & $100 \%$ & $70 \%$ & $64 \%$ \\
\hline ALERT & $\begin{array}{l}\text { Displacements on } \\
\text { the critical volume } \\
\text { confirmed by } \\
\text { GbSAR } \\
\text { monitoring. } \\
\text { Field inspections } \\
\text { confirm the } \\
\text { amplitude of the } \\
\text { unstable volume. }\end{array}$ & $\begin{array}{l}\text { Water discharge from } \\
\text { fractures; } \\
\text { Increase of thermal zero } \\
\text { altitude above } 2900 \mathrm{~m} \text { a.s.l. }\end{array}$ & $54 \%$ & $100 \%$ & $80 \%$ & $85 \%$ \\
\hline IMMINENT COLLAPSE & $\begin{array}{l}\text { Increase in the } \\
\text { frequency of small } \\
\text { rockfalls (detected } \\
\text { by automatic } \\
\text { rockfall counter) }\end{array}$ & - & $85 \%$ & $100 \%$ & $80 \%$ & $96,7 \%$ \\
\hline
\end{tabular}

Table 2. Table showing the decisional values in the Brenva site DSS. Note that the decisional values are mainly represented by qualitative 5 elements. 
Nat. Hazards Earth Syst. Sci. Discuss., https://doi.org/10.5194/nhess-2017-396

Manuscript under review for journal Nat. Hazards Earth Syst. Sci.

Discussion started: 30 November 2017

(c) Author(s) 2017. CC BY 4.0 License.

\section{Natural Hazards and Earth System Sciences \\ Discussions}

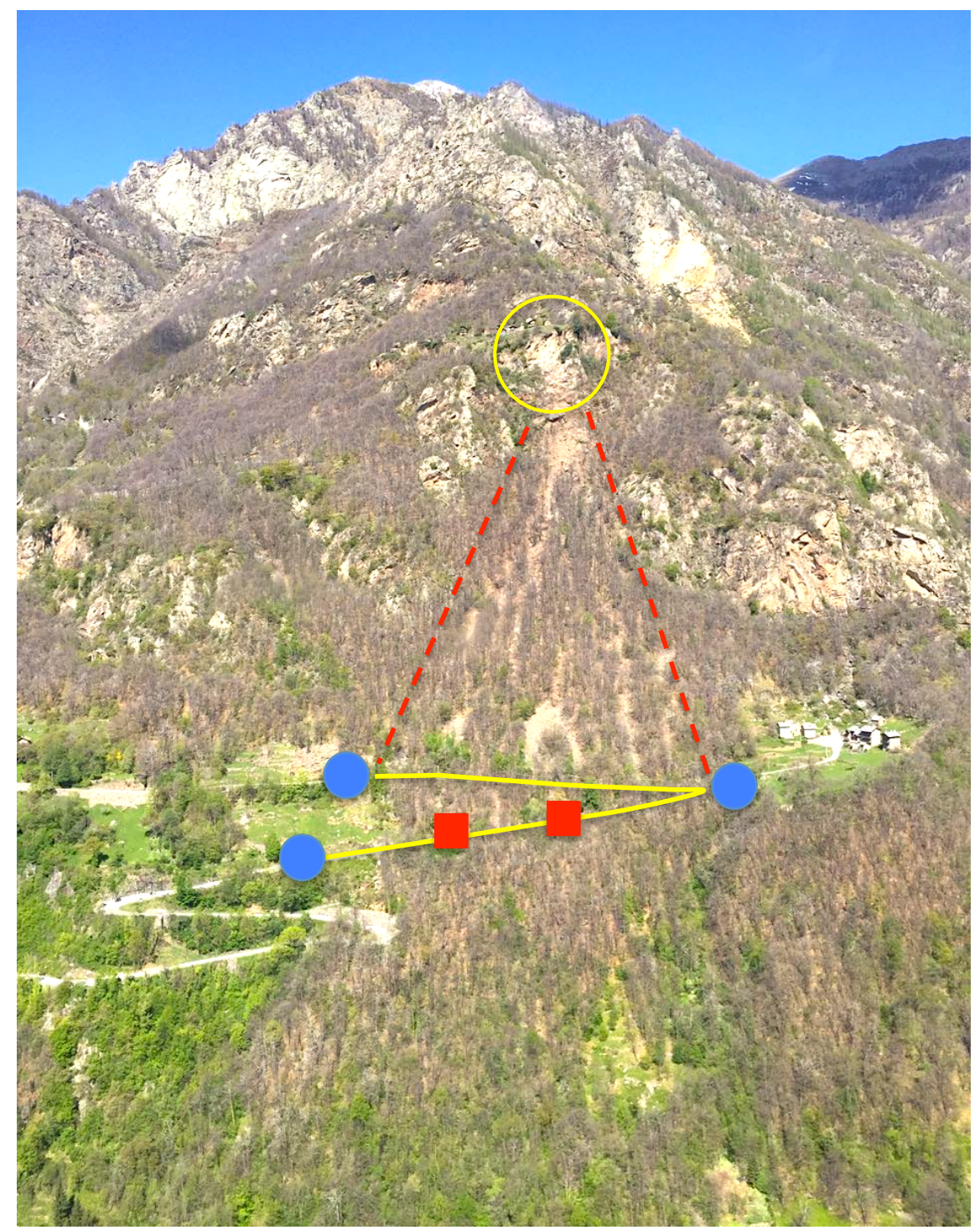

Figure 9 - The Lillianes site. The yellow circle marks the cliff where the unstable rock mass is located. The red dashed lines mark the limits of the runout zone. The two red squares mark the points where the two rockfalls hit the road on April $19^{\text {th }}$, 2017. The blue circles mark the checkpoint activated to stop the traffic circulation in case of alert on the communal route (continuous yellow line). Photo: A.

Giorgi, 2017. 
Nat. Hazards Earth Syst. Sci. Discuss., https://doi.org/10.5194/nhess-2017-396

Manuscript under review for journal Nat. Hazards Earth Syst. Sci.

Discussion started: 30 November 2017

(c) Author(s) 2017. CC BY 4.0 License.

\section{Natural Hazards and Earth System Sciences \\ Discussions}

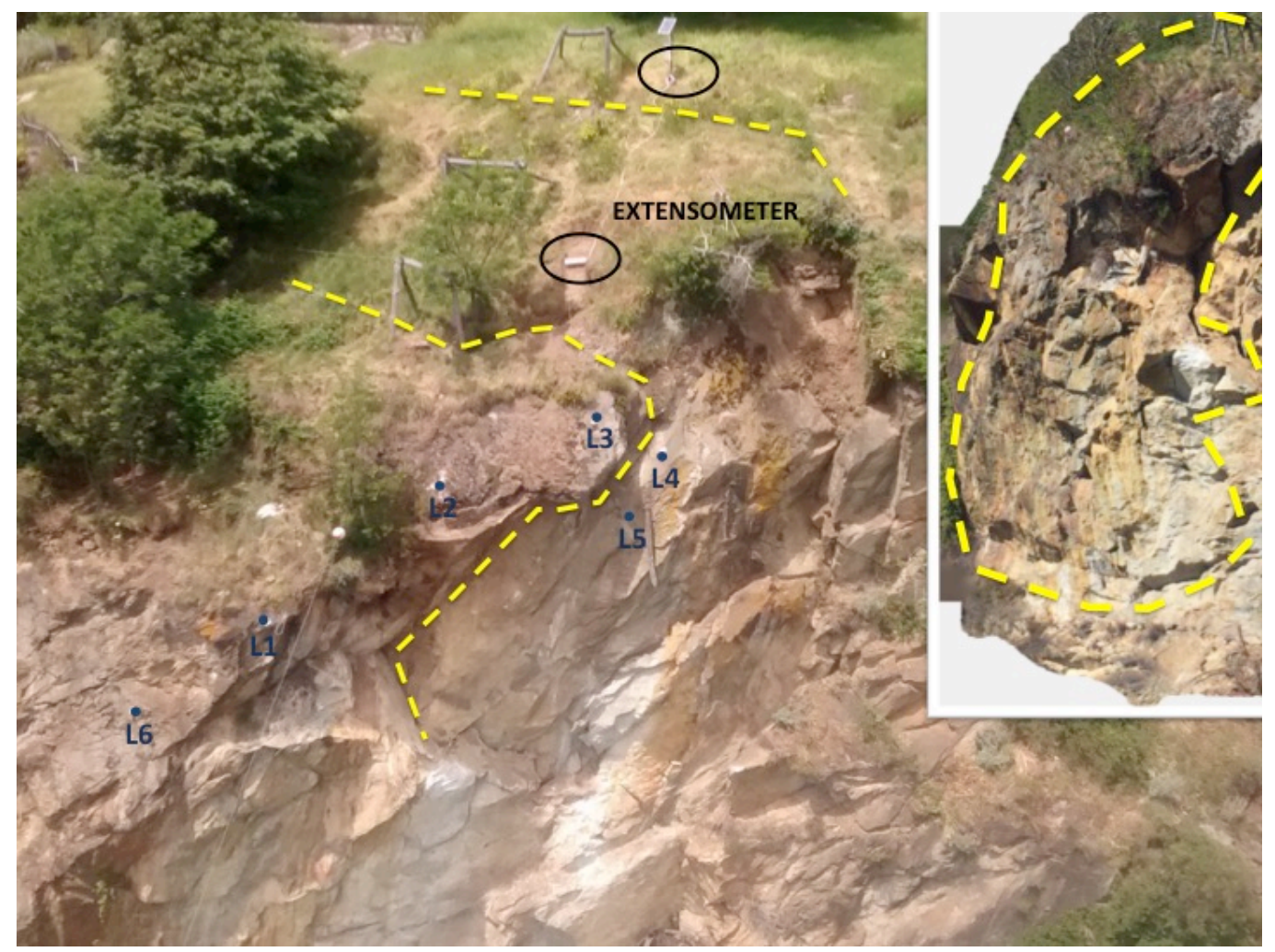

Figure 10 - Monitoring system installed at Lillianes site. The yellow dashed line marks the main cracks isolating the unstable rock mass L1-L6: RTS targets. The box (a) shows a 3D reconstruction of the unstable rock mass and the dashed line marks its boundaries. Photo: M. Ghilradini, 2017.

\begin{tabular}{|c|c|c|c|c|c|c|}
\hline WARNING LEVEL & $\begin{array}{l}\text { MAIN DECISIONAL } \\
\text { VALUE (DV) }\end{array}$ & $\begin{array}{c}\text { SUPPORTING } \\
\text { DECISIONAL } \\
\text { VALUES } \\
\text { (QUALITATIVE) }\end{array}$ & $\operatorname{Pr}$ & Se & Sp & PPV \\
\hline ORDINARY MONITORING & $\begin{array}{l}\text { LOS displacements } \\
\text { under thresholds. }\end{array}$ & - & - & - & - & - \\
\hline WARNING & $\begin{array}{l}\text { LOS displacement > } \\
5 \mathrm{~mm} \text { on a measure } \\
\text { cycle. } \\
\text { (Quantitative) }\end{array}$ & - & $20 \%$ & $100 \%$ & $90 \%$ & $71,4 \%$ \\
\hline ALERT & $\begin{array}{l}\text { LOS displacement } \\
\text { confirmed by contact } \\
\text { monitoring network } \\
\text { (strain gauge). }\end{array}$ & - & $71,4 \%$ & $100 \%$ & $90 \%$ & $96 \%$ \\
\hline IMMINENT COLLAPSE & $\begin{array}{l}\text { Visual confirm (direct } \\
\text { investigation). } \\
\text { (Qualitative) }\end{array}$ & - & $96 \%$ & $100 \%$ & $90 \%$ & $99 \%$ \\
\hline
\end{tabular}

5

Table 3. Table showing the decisional values in the Lillianes site DSS. The activation of the second alert level will lead almost immediately to the road closing with a confidence of $96 \%$. 
Nat. Hazards Earth Syst. Sci. Discuss., https://doi.org/10.5194/nhess-2017-396

Manuscript under review for journal Nat. Hazards Earth Syst. Sci.

Discussion started: 30 November 2017

(c) Author(s) 2017. CC BY 4.0 License.

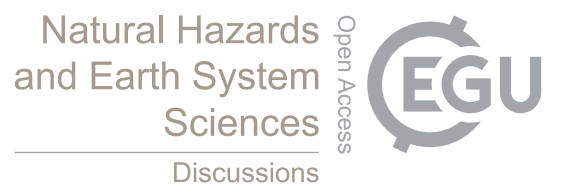

Discussions

\section{(c) (1)}

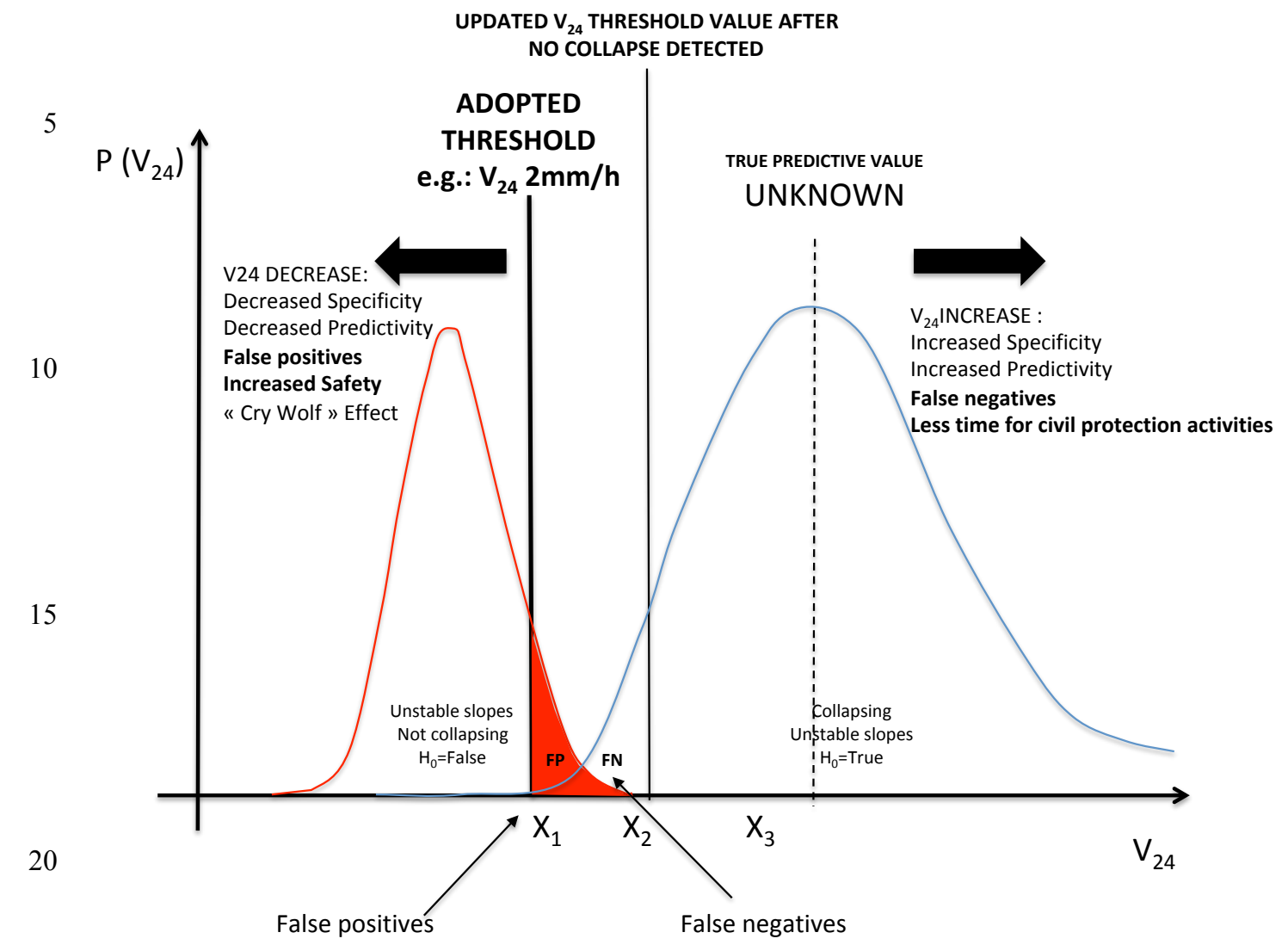

Figure 11. The effects of varying the "cutoff value", i.e. the threshold value. The two curves are FDP of the V24 threshold. To simplify, a normal distribution has been assumed. The cutoff is set at an initial value $X_{2}=2 \mathrm{~mm} / \mathrm{h}$, where false negatives are absent (the area labelled as "FN" of the blue curve). An increase in the threshold value reduces the probability of detecting the false positives but increases the probability of not detecting true positives. At the same time, shifting the cutoff towards the left increases safety but also the probability of collecting false positives. 
Nat. Hazards Earth Syst. Sci. Discuss., https://doi.org/10.5194/nhess-2017-396

Manuscript under review for journal Nat. Hazards Earth Syst. Sci.

Discussion started: 30 November 2017

(c) Author(s) 2017. CC BY 4.0 License.
Natural Hazards

and Earth System

Sciences

Discussions (c) (1)

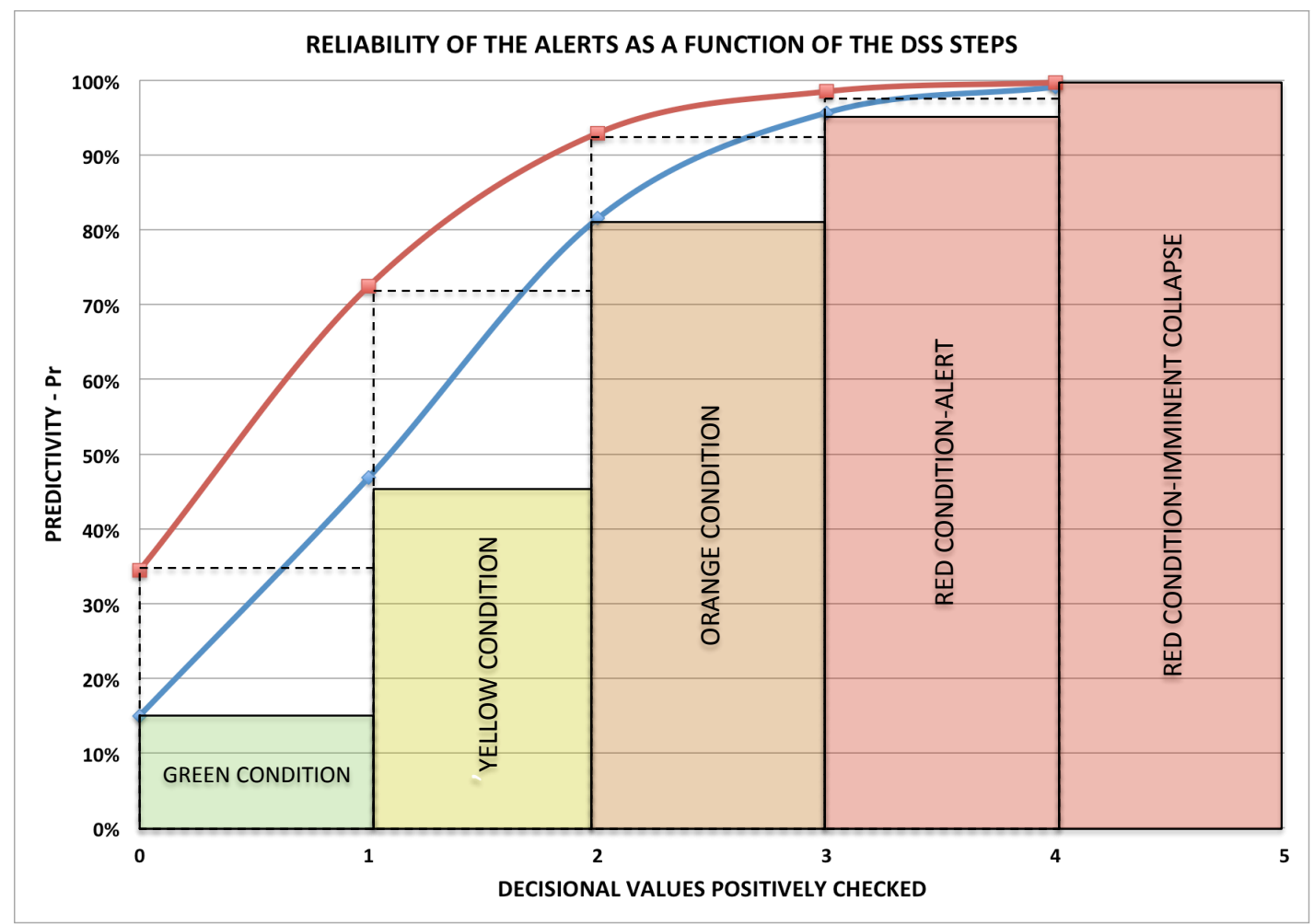

Figure 12. Increase of global PPV in the Mont de La Saxe Rockslide DSS as a new decisional value (heavy rain forecast) is added. The coloured bars show the different civil protection alert levels, according to the the Italian Civil Protection Department Directive 27.02.2004. Green Condition: "Codice Verde"; Yellow Condition: "Codice Giallo"; Orange Condition: "Codice Arancio"; Red Condition:" Codice

5 Rosso". The dashed rectangles show the increase in the probability when the new decisional value is added. The blue line interpolates the decisional values in the "standard condition". The red line interpolates the decisional values in the case of an acceleration detected during a heavy rainfall event. Note that the real function is a discontinuous one because the passages between two level of PPV are discontinuous. The continuous curve interpolating the decisional values is a graphical artefact to provide a better rendering of the increase in reliability. 